UDK: 616.89-008.442.36:[2:392:394:395:316.62

Izvorni naučni rad

Primljeno: 30. 9. 2019.

Prihvaćeno za štampu: 13. 1. 2020.

dr. sci. Muharem Štulanović, redovni profesor

Univerzitet u Bihaću

Islamski pedagoški fakultet

E-mail:ebuseba@hotmail.com

\title{
HOMOSEKSUALNOST NA MIZANU VJERE, TRADICIJE, LIJEPIH, PRIHVATLJIVIH OBIČAJA I ZDRAVE LJUDSKE PRIRODE
}

\section{Sažetak}

Pripadnici LGBTIQ zajednice, njihovi aktivisti $i$ aktivistkinje nakon dekriminalizacije homoseksualnosti $i$ uklanjanja sa spiska poremećaja nastavili su borbu za svoja posebna, specijalna prava, izlazak u javnost $i$ zakonsko izjednačavanje s heteroseksualnom zajednicom. To uključuje zaštitu ljudskih prava homoseksualaca, zakonsko priznavanje istospolnih parova, priznavanje seksualne orijentacije i rodnog identiteta kao osnove po kojima diskriminacija nije dozvoljena, uključujući tu i sva druga prava kojima se koristi društvena zajednica.

$U$ našoj zemlji, pod utjecajem mectunarodne zajednice, a ne kao plod unutrašnjeg djelovanja bilo kojih aktivističkih subjekata ili "sazrijevanja" demokratskog drustva, zabranjena je diskriminacija kroz Zakon o ravnopravnosti spolova i Zakon o zabrani diskriminacije.

Pošto se ovdje radi o kompletnoj alternativnoj kulturi oprečnoj nebeskim, objavljenim, vjerama, apsolutna većina svjetske populacije protivi se homoseksualnoj ideologiji, bez obzira na zakonska rješenja, deklaracije $i$ pravni status koji je LGBT populacija izborila. Ljudi zdravog razuma, tradicije, lijepih, pribvatljivih običaja užasavaju se teških, pa i apokaliptičnih posljedica koje bi ova populacija mogla prouzročiti (pokušaj rušenja porodice $i$ temeljnih univerzalnih moralnih vrijednosti, raznih novih oboljenja nepoznatih u prošlim vremenima koja prate ovu populaciju, depopulacija $i$ bijela kuga i slično). Sigurno je da iza drustvene, političke i pravne afirmacije 
ove populacije stoje neke svjetske 'elite' i odredeni vrlo utjecajni lobiji i centri moći (masonski, židovski, porno, farmaceutski, satanistički, džender i drugi).

Coming outom i prajd/paradama ponosa, homoseksualnelgey osobe ostvaruju svoju društvenu angažiranost, specifične aktivnosti, ideologiju $i$ javna istupanja, grade sebi svojstvenu supkulturu, tj. kontrakulturu ili alternativnu koja pruža otpor prema dominantnoj heteroseksualnoj kulturi. U posljednje vrijeme na našim prostorima došlo je do značajnih pomaka u usvajanju zakonodavstva nametnuto vanjskim faktorima i drustvenopravnim pritiscima koje bi trebalo da stiti ovu populaciju od homofobičnog ponašanja. Tako je posljednjih godina, stav prema homoseksualcima ublažen i kod nas kao što se to ranije već desilo globalno, na Zapadu. Njihova supkultura nameće se i na našim prostorima u različitim oblastima i sferama društvenog života kroz umjetnost (književnost, kulturu, muziku, pozorište, film, slikarstvo, fotografiju, festivale, strip...), djelovanje sve većeg broja LGBT organizacija, njihovog aktivizma, uz obilno korištenje medija, posebno interneta, ali isto tako prava i politike, preko jakog stranog lobija $i$ utjecaja svjetskih centara moći.

Njihova kampanja za zakonska prava $i$ ravnopravnost $u$ drustuu, pod krinkom tolerancije $i$ zastite ljudskih prava, borbe protiv diskriminacije, stereotipa $i$ homofobije, uz primjenu ultimatuma od odredenih vanjskih centara moci dovela je do usvajanja pravnih akata, deklaracija, rezolucije o zaštiti prava LGBT osoba kako na svjetskom tako $i$ na državnom $i$ regionalnom nivou.

Pošto se radi o posebnoj ciljnoj grupi, specijalnim pravima, osobenoj kulturi i pokretu, u radu smo se posebno kritički osvrnuli na Istanbulsku konvenciju $i$ dva modela njihove javne borbe za priznavanje i nediskriminaciju (Coming out i prajd/parade ponosa) jer su to trenutne aktualnosti koje se pokušavaju sprovesti na našim prostorima uz pomoć koja dolazi izvan naše zemlje.

Ključne riječi: homoseksualnost, LGBTIQ populacija, seksualna orijentacija, spol, rod, rodna ideologija, rodni identitet, coming out, prajd/parade ponosa.

\section{UVOD}

Vjera je došla zbog koristi ljudima, da bi uredila i uravnotežila ljudski život. Uzvišeni Allah nema nikakvu potrebu za nečijom vjerom, kurbanom, žrtvom, sadakom, namazom, hadžom niti bilo kakvom drugom ibadetskom aktivnošću. 
Međutim, sve vjerske aktivnosti svojom funkcijom služe za korist i dobrobit čovjeka pojedinca ili društva općenito. Vjera je objavljena upravo da bi ljude (vjernike, vjerske praktičare) fizički i duhovno održala u životu na ovom svijetu, spasila na budućem i bila orijentir jednog normalnog, ljudskog, humanog, moralnog i uravnoteženog načina života. Time se ostvaruje smisao i svrha življenja kao što to Kur'an i konstatuje:

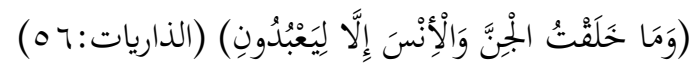

Nisam stvorio ljude i džine osim da bi Me obožavali. (Kur'an, 51: 56)

Propisi islama, njegove norme, ibadeti (obredoslovlje) imaju svevremenu aktualnost, svrhovitost, mudrost i nadnaravan božanski karakter, što se vidi i kod rješavanja savremenih praktično-pravnih i aktualnih društveno-političkih pitanja i novonastalih situacija i problema.

To se zapaža kod ozbiljnog, naučnog pogleda i pristupa u razumijevanju vjere i njenih sastavnih ibadetskih (obredoslovnih) aktivnosti.

U pokušaju elaboracije i da bi se mogli shvatiti teorijski i drugi nazori kao i složene implikacije, ideološkog LGBT pokreta kao kompleksne teme vezane za homoseksualne/gey osobe, njihovu supkulturu, tj. kontrakulturu ili alternativnu koja trenutno pruža otpor prema dominantnoj, kroz tzv. coming out i prajd/parade ponosa, njihovu društvenu angažiranost, specifične aktivnosti, ideologiju i javna istupanja, potrebno je za rasvjetljavanje i izučavanje svih tih fenomena upotrijebiti metodološki pluralizam što pretpostavlja upotrebu historijske, sociološke, filozofske, aksiološke, pravne, te metode teorijske analize i komparativni metod, s jedne strane.

$\mathrm{S}$ druge strane, pošto se radi o našim gledištima kao pripadnicima dominantne kulture ili gledišta vjernika, muslimana, onda, u potrebi smo za jasnim stavovima i razumijevanjem sve ove fenomenologije oko LGBT pokreta i njegove ideologije u svjetlu metodologije islamske jurisprudencije (usuli fikh), komentaru Kur'ana (tefsir) i stavovima muslimanskih pravnika (fikh) u ocjeni, analizi i kvalifikaciji ovih fenomena $\mathrm{s}$ islamskog stajališta koja imaju svoje posebne odlike i specifičnosti. 
Smatramo da su vrijednosti, s kojima dolazi božanski sistem islama, posebno u oblasti božanske antropologije, porodičnog i bračnog prava, od krucijalne važnosti za kompletno čovječanstvo. Pravna zaštita tradicionalne porodice i braka, u konstelaciji apokaliptičnih, savremenih odnosa gdje su napadnute njihove univerzalne vrijednosti, dovedena $\mathrm{u}$ pitanje $\mathrm{i}$ sama opstojnost i reprodukcija čovječanstva, obaveza je i misija pravnih učenjaka na bilo kom prostoru majke Zemlje.

Primjenjujući spomenuti metodološki pluralizam u izučavanju i osvjetljavanju fenomena ove teme, koristit ćemo svaku od spomenutih metoda u domenu njenih određenih spoznajnih granica i mogućnosti. Naravno, pošto se radi o alternativnoj kulturi koja je oprečna svim objavljenim, monoteističkim vjerama i zbog nesporne činjenice da se apsolutna većina svjetske populacije protivi homoseksualnoj ideologiji, bez obzira na zakonska rješenja, deklaracije i pravni status, užasavajući se njenih teških posljedica (pokušaj rušenja porodice i temeljnih univerzalnih moralnih vrijednosti, raznih novih oboljenja nepoznatih $u$ prošlim vremenima koja prate ovu populaciju, depopulacija, bijela kuga i slično), mnogi osnovano tvrde da iza njene društvene, političke i pravne afirmacije stoje neke svjetske 'elite' i određeni vrlo utjecajni lobiji i centri moći (masonski, židovski, porno, farmaceutski, satanistički, džender i drugi), što sigurno nije daleko od istine.

\section{DEFINICIJA I NEKE HISTORIJSKE ČINJENICE}

Bratoljub Klaić definiše homoseksualizam kao protuprirodnu spolnu sklonost prema

osobama istog spola ${ }^{1}$ tako da se ovaj izraz danas primarno koristi $u$ literaturi, ali u modifikovanom izrazu homoseksualnost umjesto ranije sodomija, pederastija, lutijstvo, grčka ljubav; dok se osobe homoseksualne orijentacije $\mathrm{u}$ običajenoj korespodenciji nazivaju pogrdnim, uvredljivim nazivima: peder, peško, perverznjak, seksualno nenormalan, devijantan, bolestan, topli brat; a žene: lezbače, žene koje mrze muškarce, muškarače, seksualno devijantne, bolesne, ženski petko, tetka itd.

\footnotetext{
${ }^{1}$ Klaić, Bratoljub, Rječnik stranih riječi, Nakladni zavod MH, Zagreb, 2004., str. 554.
} 
Kao odgovor na sve to, pripadnici i promotori ovog pokreta kroz uljepšavanje i pomno odabrane i smišljene savremene nazive, metodom uljepšavanja i preimenovanja, nastoje ove pogrdne izraze staviti $u$ zaborav jer simbolizuju milenijsko, dugo, prošlo vrijeme zabrane i diskriminacije ovog vida seksualne orijentacije i nezakonitog ponašanja kroz historiju, ne bi li ovaj pokret ili njegovu supkulturu predstavili kao nešto potpuno normalno ili čak poželjno.

To je sotonska/šejtanska metodologija koja se "kalila, inovirala i modelirala" od početka stvaranja ljudskog roda do danas. Naime, šejtani/đavoli/demoni predstavljaju skrivenog smrtnog neprijatelja ljudskom rodu, koji neprestano pokušava moralno pokvariti ljude i njihova vjerovanja, unijeti među njih mržnju i neprijateljstvo. Zbog toga veliki broj ajeta u Kur'anu i predaja od Allahovog Poslanika, a.s., upozoravaju na ovu opasnost, kao i na metodologiju i načine njihovog zavođenja, kako bi se ljudski rod spasio od zla, preduprijedio njihov eshatološki izgovor i opravdanja na pogreške.

Uzvišeni kaže:

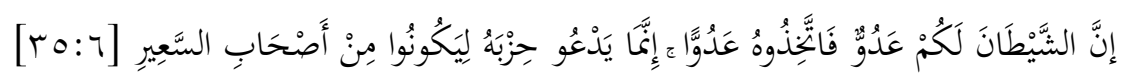

Šejtan je, uistinu, vaš neprijatelj, pa ga takvim i smatrajte! On poziva pristaše svoje da budu stanovnici u vatri. (Kur'an, 35: 6)

Ovo je eksplicitno otkrivanje đavoljeg, sotonskog neprijateljstva prema ljudskom rodu i Ademovim potomcima koje je konstantno. Nikada ne dolazi u pitanje i zbog toga su ljudi u obavezi da i oni, prema njemu,

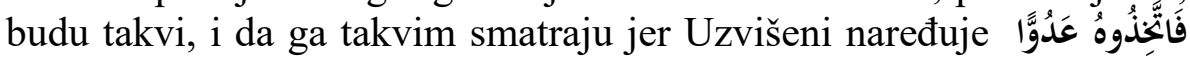
(pa ga smatrajte i uzimajte za neprijatelja).

Uzvišeni se nije zadovoljio samo s ovim oglašavanjem, nego slijede mnogobrojni drugi ajeti koji pojašnjavaju šejtanske đavolije i njegove sotonske metode u zabluđivanju:

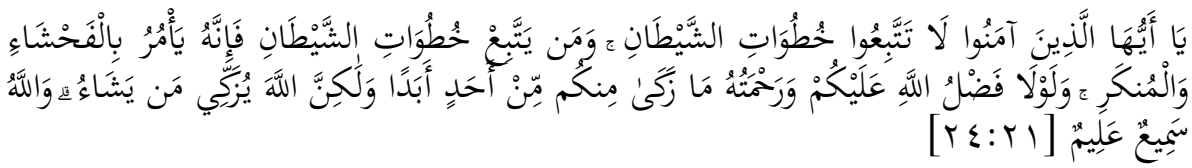

O vjernici, ne idite šejtanovim stopama! (Ne slijedite njegovu metodologiju i njegove vragolije). Onoga ko bude išao šejtanovim stopama on će na razvrat i odvratna djela navoditi. A da nije Allahove dobrote prema vama i milosti Njegove, nijedan se od vas ne bi nikad od 
grijeha očistio; ali Allah čisti onoga koga On hoće. Allah sve čuje i sve zna. (Kur'an, 24: 21)

Šejtan/sotona nije zadovoljan time da čovjeka samo uvede u zabludu i griješenje, nego mu to uljepša, ne ostavljajući ga da mu proradi savjest. On mu usadi osjećaj unutrašnjeg smirenja i zadovoljstva s nezakonitim postupcima tako da osoba ne osjeća grižnju savjest i kajanje zbog toga:

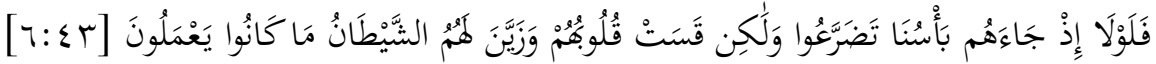
Trebalo je da su poslušni postali kad bi im kazna Naša došla! Ali, srca njihova su ostala tvrda, a šejtan im je lijepim prikazivao ono što su radili. (Kur'an, 6: 43)

I to ulješavanje je metod zavođenja:

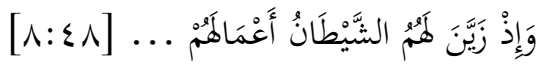

I kada im je šejtan kao lijepe njihove postupke prikazivao... (Kur'an, 8: 48)

Što se tiče savremenog izraza LGBT, to je sveobuhvatni pojam koji označava lezbejke, gej muškarce, biseksualne i transrodne osobe. Ovaj pojam označava heterogenu skupinu u društvenom i političkom aktivizmu, a može se proširiti uključujući i interseksualne i queer osobe (LGBTIQ).

Stajalište velikog crkvenog reformatora Tome Akvinskog o ljubavi i homoseksualnosti kod čovjeka, odražava milenijski stav premo ovoj populaciji:

"U stečene vrline Toma ubraja već postojeće Aristotelove etičke i dijanoetičke (umne) vrline, dok se u ulivene vrline ubrajaju tri kardinalne kršćanske vrline: fide, spes, et caritas (vjera, nada i ljubav). Neka od Tominih etičkih stanovišta zanimljiva su i za današnje rasprave: on drži da je homoseksualnost protuprirodna jer je protivna Božijim zakonima. Homoseksualni seks je prema njima gori od preljuba, incesta i silovanja jer čovjek nije stvoren za takvu vrstu odnosa sa istim spolom. Toma Akvinski čak uspoređuje homoseksualnost $\mathrm{s}$ čovjekoubojstvom jer je nespojiva s prirodnim 
dobrom, očuvanjem vrste, odnosno, pretpostavlja destrukciju ljudske egzistencije." 2

Na Wikipediji nalazimo kratku historiju homoseksualnosti i borbe pripadnika LGBTIQ zajednice za njihova posebna, specijalna prava, priznavanje i javno, zakonsko izjednačavanje s heteroseksualnom zajednicom:

"Nakon dekriminalizacije homoseksualnosti i uklanjanja sa spiska poremećaja, LGBT aktivisti i aktivistkinje su nastavili borbu za izjednačavanje prava LGBT osoba s pravima ostalih. Ova prava uključuju priznavanje seksualne orijentacije i rodnog identiteta kao osnove po kojima diskriminacija nije dozvoljena, zakonsko priznavanje istospolnih parova uključujući tu i ona prava koja proizlaze iz zajednice, kao što su pitanja nasljeđivanja, bolničkih posjeta, penzionog i zdravstvenog osiguranja, plaćanja poreza, imigracionih i roditeljskih prava i sl.

Prva zemlja koja je u potpunosti izjednačila prava homoseksualnih osoba s ostalima je Holandija - priznavanjem istopolnih brakova, 2001.

Taj primer su slijedile Belgija (2003), Španija (2005), Kanada (2005), Južna Afrika (2006), Norveška (2009), Švedska (2009.) i nekoliko država u SAD, kao i grad Meksiko. U drugim državama postoje drugačiji oblici priznavanja istospolnih zajednica, kao što su registrovano partnerstvo, građanska zajednica i sl.

Nasuprot razvijenim demokratskim državama, u svetu postoji još veliki broj država u kojima je homoseksualnost krivično delo (uglavnom u Africi i Aziji), kao i šest država koje još uvek predviđaju smrtnu kaznu za homoseksualnost."3

U djelu "Čitanka LGBT ljudskih prava", 2. dopunjeno izdanje Sarajevo, 2012. autor, Aida Spahić, govori o homofobiji (diskriminacija pripadnika homoseksualne orijentacije) i navodi:

"Diskriminaciju ljudi nehetero seksualne orijentacije i "drugačijih" rodnih identiteta možemo pratiti već stoljećima. Od ranog srednjeg

${ }^{2}$ Porobija, Željko, Povijest razvoja teologije od apostolskih otaca do konca srednjega vijeka, Adventističko teološko visoko učilište, Maruševec, 2011. str. 134.

${ }^{3}$ https://sh.wikipedia.org > wiki > LGBT_istorija, posjećeno 25. septembra, 2019. 
vijeka mržnja prema ljudima koji nisu heteroseksualne orijentacije počinje da se institucionalizira, primarno kroz crkvene strukture. Počinju progoni homoseksualaca, lažne optužbe za homoseksualnost (koja se tada nazivala sodomija) u svrhe postizanja političkih ili drugih ciljeva. Jedan od primjera jeste red templara koji je cijeli uništen upravo po ovim osnovama. Iako je homoseksualnost bila nešto što se aktivno pokušavalo iskorijeniti, služila je i kao sredstvo za ucjene, klevete i optužbe. Tokom stoljeća koja su uslijedila, osobe optužene za homoseksualnost bile su u sadašnjim evropskim zemljama podvrgavane kaznama kao što su utapanje, davljenje, odrubljivanje glave, kastriranje, vješanje, spaljivanje i slično (Mondimore 2003: 187). Iako su dolaskom prosvjetiteljstva ovakve kazne znatno smanjene, počinju se pojavljivati kvazimedicinske i kvazinaučne teorije o degeneracijama i iznalaziti raznorazna opravdanja za formalnu kriminalizaciju homoseksualnosti (Mondimore 2003: 187). Tokom dvadesetog stoljeća homoseksualnost je bila kriminalizirana u skoro svim zemljama, i povlačila je za sobom dugotrajne i stroge kazne. U modernom dobu, sve dok u većini zemalja nije dekriminalizirana homoseksualnost i dok nije zvanično skinuta s liste psihičkih oboljenja, postojale su razne teorije kojima se dokazivalo da se homoseksualnost može liječiti, nerijetko elektrošokovima i sličnim nehumanim metodama. Većina istraživanja na kojima su se ove teorije temeljile vršena je u psihijatrijskim institucijama i zatvorima, te su se tako donosili zaključci koji su se primjenjivali na cjelokupnu populaciju (Mohr 2003)."

Heteronormativni odgoj uči da je osnovna ćelija društva porodica koja se sastoji od muškarca, žene i djece. Brak predstavlja uslov za opstanak čovječanstva dok homoseksualizam i slične partnerske zajednice predstavljaju prijetnju uništenja porodice kao osnovne ćelije društva čime se urušava cijela ljudska civilizacija i čiji fizički opstanak i reprodukcija dolaze u pitanje. Postoji strah i latentna opasnost da će istospolni brakovi, u slučajevima posvojenja, odgajati homoseksualnu djecu kao i teza da je to neprirodna zajednica koja ne može imati djecu.

${ }^{4}$ Čitanka LGBT ljudskih prava, 173. 
Pod takvim opravdanjima heteronormativno društvo ne prihvata ovaj vid seksualne orijentacije i na ovim osnovama se, po zagovornicima ovih ideja, "rađa tzv. homofobija.",

A “pojmom (homofobija) označava se negativan stav prema ljudima koji ulaze u seksualno-emocionalne veze s osobama istog spola $u$ vidu homoseksualnih veza i partnerstava. Pojam se sastoji od grčke riječi homós koja znači isti, jednak i riječi phóbos koja označava strah."

Homofobijom se kao crvenim platnom maše pred licima protivnika u pokušaju da se heteronormativno društvo natjera na priznavanje ove pojave kao normalne te specijalnim zakonskim rješenjima zaštiti od diskriminacije. Ili još više od toga, da se odnosom prema homoseksualnosti "mjeri stepen demokratije u jednoj zemlji”, što znači da takvo ponašanje postaje standard. To su uvrnuti, izopačeni standardi. Demokratija se ne mjeri prema stepenu intenziteta neprijateljstva, nekontrolisane sile ili agresije prema nedužnim civilima, svakodnevnim ubijanjima i uništavanjima čitavih država (krucijalni je razlog što se radi o žrtvama muslimanima), nego hoće li se desiti parade ponosa i sl. To je samo dno antietičnosti i nemorala!

Gdje je u svemu ovome Bosna i Hercegovina i njeno multinacionalno i multikonfesionalno društvo?

"Pod utjecajem međunarodne zajednice, a ne kao plod aktivističkog djelovanja zajednice, naša zemlja je zabranila diskriminaciju kroz dva zakonska akta: Zakon o ravnopravnosti spolova i Zakon o zabrani diskriminacije. Dalje od toga se nije otišlo. Zasad možda i dovoljno. Značaj ovih zakona je u tome što su oni: državni i sistemski. Oni uvode obavezu usklađivanja drugih propisa s njima, te konačno sistemski rješavaju pitanje zabrane diskriminacije u Bosni i Hercegovini.",

"U posljednje vrijeme na našim prostorima došlo je do značajnih pomaka u usvajanju zakonodavstva koje bi trebalo da štiti sve ljude od homofobičnog ponašanja. Do takvog koraka nije došlo zbog toga što je društveni razvoj došao do tačke shvatanja da homofobija nije uredu, već zbog toga što je usvajanje zakona nametnuto vanjskim faktorima $\mathrm{i}$

\footnotetext{
${ }^{5}$ Uporedi, ibid.: 212.

${ }^{6}$ Ibid, 209.

${ }^{7}$ Ibid., 144.
} 
ljudskopravaškim pritiscima. Sada država može da radi na normalizaciji jer "svi imaju sva prava i šta ti ljudi još hoće?" Danas imamo dvije najagresivnije manifestacije homofobije koje dalje utječu na produbljivanje institucionalne homofobije koja se sistemski širi i oduzima ili otežava realizaciju zakonom zagarantiranih prava - govor mržnje i fizičko nasilje. Krivična djela počinjena iz mržnje prema LGBTIQ osobama nisu specifična samo za ove prostore. Vijeće Evrope navodi da se takva djela dešavaju u svim zemljama članicama Vijeća Evrope. Ova djela su uvijek izuzetno brutalna i okrutna te nerijetko vode u smrt." 8

I na našim prostorima posljednjih godina, stav prema homoseksualcima je ublažen kao što se to desilo i na globalnom planu tako dok su u mnogim zapadnim zemljama afirmativne slike gej veza uobičajene $u$ medijima i štampi, a sve više se ta ideja nameće na našim prostorima $u$ različitim oblastima i sferama društvenog života kroz umjetnost (književnost, kulturu, muziku, pozorište, film, slikarstvo, fotografiju, festivale i strip), ali i kroz djelovanje sve većeg broja LGBT organizacija, studija i aktivizma, uz obilno korištenje medija, posebno interneta, ali isto tako prava $\mathrm{i}$ politike, preko jakog stranog lobija i uticaja svjetskih centara moći.

Kampanja za zakonska prava i ravnopravnost u društvu, pod krinkom i pod motom tolerancije, borbe protiv diskriminacije i zaštite ljudskih prava, stereotipa i homofobije, te $\mathrm{u}$ određenim slučajevima i uz primjenu ultimatuma od određenih centara moći dovela je do usvajanja mnogih pravnih akata, deklaracija, rezolucija, paktova o zaštiti prava LGBT osoba na svjetskom i regionalnom nivou.

Ipak, "homoseksualnost kod nas mnogi stručnjaci još uvijek smatraju poremećajem (Zulević 2001: 118). Ne tako davno, 1973. godine, Američki psihijatrijski savez je skinuo homoseksualnost sa liste mentalnih bolesti." 9

Naravno, njihovi lobiji uspjeli su 1972. i 1973. godine pridobiti vodeće ljude u Američkom udruženju psihijatara pa su nizom poteza i izravnih obmana preko noći unormalili ili "izliječili” homoseksualce - sudskim

\footnotetext{
${ }^{8}$ Ibid., 218.

${ }^{9}$ Ibid., 216
} 
nalogom i proklamacijom "kako odnos s istim spolom nije poremećaj, nego samo 'stanje' jednako neutralno kao i ljevorukost."

Charles W. Socarides će tim povodom napisati: "Mi koji se nismo suglasili sa tom novom političkom definicijom ubrzo smo ušutkani na vlastitim stručnim sastancima. Na sveučilištima su ukinuta naša predavanja, a znanstveni časopisi odbijali su nam objavljivati znanstvene radove." 10

Tako je i Svjetska zdravstvena organizacija (WHO - World Health Organization)

1990. godine uklonila homoseksualnost iz Međunarodne klasifikacije bolesti (ICD-9). ${ }^{11}$

Politika, lobiji, mediji i 'elite' u svjetskim, globalnim okvirima često izokrenu i izopače stvarnost $\mathrm{i}$ istinu od koje naprave neistinu, od neistine istinu, od jahača apokalipse zaštitnike demokratije i borce za ljudska prava i nediskriminaciju, od kukavice junaka, od junaka kukavicu, od dželata žrtvu, a od žrtve dželata, teroristu itd. Provjerena metoda zamjene teza!

\section{MODELI NJIHOVOG DJELOVANJA I BORBE}

Aktivisti homoseksualne orijentacije i gej-prava koriste elemente modernog marketinga, medije, kulturu, pravo, sportske i druge manifestacije, znanost, retoriku, psihologiju da bi se pozicionirali tako da društveni tokovi i rasprave o njoj idu u smjeru koji oni promoviraju i koji odgovara njima i njihovim interesima. Na tom planu su specijalno angažovane mnogobrojne nevladine organizacije i umrežene LGBT organizacije koje vode propagandni (marketinški) rat za svoj interes u svim mogućim medijima koji su njima dostupni, posebno na internetu, te kroz mnogobrojne besplatne knjige, radove, letke, časopise, brošure i uputstva u kojima se iscrpno govori o coming outu, paradama ponosa

\footnotetext{
${ }^{10}$ Charles W. Socarides, M.D., How America Went Gay (http://www.theroadtoemmaus.org/ (RdLb/22SxSo/PnSx/HSx/SocrdsHowAmerGay.htm ). Posjećeno, 25. septembra, 2019.

${ }^{11}$ Čitanka LGBT ljudskih prava, str. 14.
} 
i njihovom značaju, posljedicama i svim mogućim aspektima te pojave i njihovog pozicioniranja u društvu.

S obzirom na historijske, političke, duhovne i druge tokove razvoja kulture nekog društva, LGBT kultura je dio tog procesa i postoji kao specifična, alternativna supkultura. Kada je u pitanju odnos opće kulture i LGBT kulture, može se primijetiti da je LGBT kultura (ponekad se može nazivati i gej kulturom ili queer kulturom) u 21 . stoljeću, prihvaćena u mnogim zemljama makar se $\mathrm{s}$ njom ne identificiraju ni sve osobe te seksualne orijentacije i/ili rodnog identiteta. U svijetu, regionu ali i kod nas postoje gotovo nebrojene organizacije koje se bore za promociju homoseksualnosti afirmišući njihovu kulturu kroz sve moguće vidove umjetnosti, filma, muzike, teatra, stripa, TV-a, reality showova, TV serija, mode, književnosti...

Kada je riječ samo o festivalima, kao sredstvu njihovog marketinga $i$ predstavljanja, u svijetu se već redovno održava više od 150 queer filmskih festivala kojima se, uspostavlja i jača veza s političkim i društvenim gej i lezbejskim pokretima, a muzika kao konzument mladih isto tako sve više postaje medij za promociju homoseksualnosti $\mathrm{i}$ iskazivanje otpora heteronormativnom sistemu.

Izdvajamo da se s pravnog aspekta kritički osvrnemo na Istanbulsku konvenciju i dva modela njihove javne borbe za priznavanje i nediskriminaciju jer su to trenutne aktualnosti koje se pokušavaju sprovesti na našim prostorima:

1. Istanbulska konvencija

2. Coming out $\mathrm{i}$

3. prajd/parade ponosa

\section{ISTANBULSKA KONVENCIJA}

Istanbulska konvencija je skraćeni naziv za Konvenciju Vijeća Evrope o sprečavanju i borbi protiv nasilja nad ženama i nasilja u porodici/obitelji. Vijeće Evrope prihvatilo ju je 11. maja 2011. u Istanbulu.

Ona ima status međunarodnog ugovora i time je pravno jača od nacionalnih zakona. Države koje ratificiraju Konvenciju trebaju joj 
podrediti i prilagoditi svoje ostale zakone i podložne su kontroli međunarodne skupine pod nazivom GREVIO $^{12}$ koja nadzire provedbu Konvencije, osobito na području državnih javnih politika (školstvo, mediji, antidiskriminacijska politika...).

$\mathrm{BiH}$ je istu ratificirala među prvima u Evropi, 7. novembra 2013. Time je Bosna i Hercegovina, uz Albaniju, Crnu Goru, Portugal i Tursku, postala peta članica Vijeća Evrope koja je ratificirala Istanbulsku konvenciju.

To govori kako su to uradili naslijepo, bez udubljivanja u bit, srž i ciljeve Konvencije. Da je to tako dobro, prvo bi je potpisale i ratificirale ostale evropske zemlje ili zemlje članice Vijeća Evrope, a ne prvo tih pet za Evropu beznačajnih zemalja.

U šest godina postojanja, do kraja 2017. godine, Konvenciju su ipak ratificirale 24 zemlje od ukupno 47 zemalja članica Vijeća Evrope, odnosno 14 od ukupno 28 članica Evropske unije.

U Hrvatskoj ju je 2013. godine potpisala SDP-ova vlada. Hrvatski sabor je tek 13. aprila 2018. ratificirao Istanbulsku konvenciju. I Hrvatska je postala 26. članica Vijeća Evrope koja je potpisala Konvenciju.

\section{NEPRIHVATLJIVE STAVKE I IDEOLOGIJA U ISTANBULSKOJ KONVENCIJI}

Istanbulskoj konvenciji u pravnom smislu mogu se uputiti sljedeće primjedbe:

\section{Uvođenje pojma ,roda“ i kvazinaučne ,rodne teorije $e^{66}$}

Definicija roda tvrdi da je ,rod“ društveni konstrukt i varijabla koja je neovisna o spolu, o biološkoj stvarnosti i Božijoj antropologiji u stvaranju čovjeka. Odvojenost spola i roda (vidljiva i u čl. 4. st. 3.) za posljedicu ima stvaranje uvjerenja da se čovjek rađa kao neutralno biće koje kasnije može odabrati hoće li biti muškarac ili žena ili neki drugi od brojnih „rodova“ (homo, gay, lesbian, queer, trans...).

Odvojenost spola i roda potpuno je jasna iz tačke 53. pojašnjavajućeg izvještaja (službenog dijela Konvencije): "Određene skupine

\footnotetext{
12 The Group of experts on action against violence against women and domestic violence - GREVIO
} 
pojedinaca mogu doživjeti diskriminaciju na temelju rodnog identiteta, što jednostavno rečeno znači da rod s kojim se poistovjećuju nije u skladu sa spolom koji im je dodijeljen pri rođenju."

Za vjernike, muslimane to je neprihvatljivo jer Uzvišeni Allah kazuje, eksplicitno:

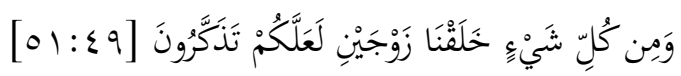

i od svega po par stvaramo da biste vi razmislili! (Kur'an, 51: 49)

Nije kazano, "stvaramo muško i muško" te "žensko i žensko" nego par! Muško i žensko!

\section{Neusklađenost s Ustavom}

Prihvaćanje te definicije zahtijeva identifikaciju s određenim dogmama rodne teorije koje nemaju svoje znanstveno uporište (naprotiv dokazano su kvazinaučne) niti ustaljeno mjesto unutar pravnog poretka. Primjerice, Konvencija (u čl. 4. st. 3) među moguće temelje diskriminacije stavlja pojmove poput „roda“, „rodnog identiteta" i „seksualne orijentacije“, dok oni ne postoje u Ustavu. Dakle, Ustav će se morati, pošto je ratificirana Konvencija pravno jača, mijenjati i uskladiti!!!

Također, te dogme nemaju veze s borbom protiv nasilja nad ženama, djecom i porodicom. U BiH su svi društveno-politički subjekti suglasni oko osude i sankcioniranja svakog nasilja nad ženama i nasilja u porodici, tako da je s te strane Konvencija suvišna.

\section{Iskorjenjivanje vjere, tradicije i porodičnih/obiteljskih vrijednosti}

Konvencija obavezuje stranke potpisnice da kulturu, običaje, vjeru i tradiciju, u mjeri u kojoj se razlikuju od načela $i$ što je najgore $i$ najopasnije od tumačenja ove Konvencije, koja mogu biti subjektivna, trebaju potčiniti ciljevima Konvencije (v. čl. 12 st. 5). Stranke će osigurati da se kultura, običaji, vjera, tradicija ili takozvana "čast" neće smatrati opravdanjem za bilo koje djelo nasilja obuhvaćeno područjem primjene ove Konvencije). Ko će i kako, te kojom metodom i subjektivnošću tumačiti izraz „nasilje“, i kako će se birati i određivati „ukidanjem zakona i praksi koji diskriminiraju žene“. 
3. Stranke će osigurati provedbu odredaba ove Konvencije, a osobito mjera za zaštitu prava žrtava, bez diskriminacije po bilo kojoj osnovi kao što su spol, rod, rasa, boja kože, jezik, vjera, političko ili drugo uvjerenje, nacionalno ili socijalno porijeklo, pripadnost nacionalnim manjinama, imovinsko stanje, rođenje, seksualna orijentacija, rodni identitet, dob, zdravstveno stanje, invaliditet, bračno stanje, migrantski, izbjeglički ili drugi status.

Konvencija, čl. 12 st. 1 Članak 12. - opće obaveze: 1. Stranke će poduzeti potrebne mjere za promicanje promjena $u$ društvenim $i$ kulturnim obrascima ponašanja žena $i$ muškaraca $s$ ciljem iskorjenjivanja predrasuda, običaja, tradicija $i$ svih drugih postupanja u praksi koja se temelje na ideji manje vrijednosti žena ili na stereotipnim ulogama žena i muškaraca; traži iskorjenjivanje svih „predrasuda, običaja i tradicija“ koje se temelje na „stereotipnim ulogama žena i muškaraca“. Konvencija ne definira koje su to stereotipne uloge, a različite zemlje i različite društvene skupine ih vrlo široko tumače, do te mjere da neke od njih $\mathrm{i}$ temeljne porodične/obiteljske uloge poput majčinstva $i$ očinstva nazivaju nepoželjnim stereotipnim rodnim ulogama, što je pravni, običajni i tradicijski nonsens.

Također, muško-ženska slika čovječanstva, obitelji i braka koja je u skladu s prirodom muškarca i žene, kao takva podržana od strane svjetskih kultura i svih velikih religija, ratifikacijom Konvencije bi mogla biti stigmatizirana kao zastarjela i nepoželjna "tradicija na temelju stereotipnih rodnih uloga“.

Sasvim je logično da zbog zacrtanih odredaba kao i ciljeva koji se time postižu pobornici homoseksualne kulture ili supkulture optužuju i vide božanske religije i njihov moralni i pravni sustav kao neprijatelja i zapreku ostvarenju "njihovih, specijalno njima namijenjenih prava":

"Iako nam je javni diskurs prožet pričom o seksualnosti i seksualno oslobađanje je uspjelo da slomi dugotrajnu šutnju i represiju javnog bavljenja seksualnošću, ona još uvijek predstavlja tabu-temu. Seksualnost se tabuizira u porodici, kasnije u društvu, a kontrolira se nametanjem braka ${ }^{13}$ i neophodne reproduktivne funkcije. Zbog toga

13 Zamislite samo šovinističku upotrebu izraza „nameće“, mada se u zakonskim rješenjima čitave regije koja govori b/s/h jezikom, striktno govori o voljnom činu 
imamo podjelu seksualnosti na prirodnu i neprirodnu gdje prirodna proizvodi djecu i dešava se isključivo u braku i na onu neprirodnu koju treba izliječiti jer je nemoralna, promiskuitetna i prijeti našoj djeci. Religija je svakako najzaslužnija za tabuiziranje seksualnosti i zajednički s tradicionalnim i običajnim normama kontrolira i sputava svaku vrstu seksualne slobode. Seksualnost je tabuizirana do te mjere da je sramno o njoj pričati, sramno je čak i misliti na postojanje seksualne želje. ${ }^{14} \mathrm{U}$ takvim okolnostima represivnog sputavanja, javlja se nedovoljno razumijevanje primarno vlastite, a onda i drugačije seksualnosti." 15

\section{IDEOLOGIZACIJA - Nametanje rodne ideologije najranjivijim kategorijama društva: djeci u vrtićima, mladima u školama i javnosti u medijima}

Konvencija (u čl. 14. st. 1) zahtijeva od stranaka potpisnica da uključe pitanja ,roda“ $i$,nestereotipnih rodnih uloga“ u redovni nastavni plan i program, i to na svim razinama obrazovanja. Njena ratifikacija tako otvara realnu opasnost da se našoj djeci u školama nameće ideologija. Djeca bi se kroz TV programe, dječije vrtiće i škole podučavala da dječaci mogu po 'rodu' biti djevojčice, a djevojčice po 'rodu' dječaci i sl. To bi bilo iznimno zbunjujuće i pogubno za njihov psihološki razvoj.

Nametanjem ideologije djeci, Konvencija ugrožava i pravo roditelja da budu primarni odgajatelji svoje djece jer, jednom kad se Konvencija ratificira, dogma o odvojenosti spola i roda postaje obavezujuća.

dvije osobe suprotnog spola koje autonomno odlučuju i daju pristanak na brak... Nema govora o nametanju, nego je to uobičajena i prirodna stvar koju društvo prihvata.

14 Ovo je toliko daleko od istine da autor izgleda nema pojma o univerzalnim vrijednostima islama kao pravnog sistema koji do $\mathrm{u}$ detalje pravno regulira seksualnost, ali na normalan način i kroz brak, da su o tome napisane biblioteke knjiga koje govore o svim aspektima slobodne veze između mladenaca od upoznavanja, dogovora braka, do prve bračne noći, pa čak i razvoda i svih drugih pitanja bračnog prava. To što je autor nepismen u pogledu poznavanja šerijatskog prava ili kur'anskog svetog teksta koji se ne libi spomenuti čak ,ferdž“ (ženski polni organ) ili seksualni odnos u ajetima koji se javno uče svakodnevno na dnevnim namazima muslimana, govori da nema govora o tabuima seksualnosti, tako da je nepoznavanje tih religijskih aksioma sramota i za nepismenog, a kako tek za intelektualca.

${ }^{15}$ Čitanka LGBT ljudskih prava, str.: 213. 
Time se suzuje prostor pluralizma, i to ne samo u školstvu. Konvencija, naime, (u čl. 14. st. 2.) predviđa širenje rodne ideologije i u ,neformalnim obrazovnim okruženjima, sportskim i kulturnim okruženjima, okruženjima za slobodno vrijeme te u medijima".

\section{Princip ,uzmi ili ostavi“6}

Istanbulska konvencija je prvi međunarodni ugovor u povijesti Vijeća Evrope u čijem sastavljanju nisu sudjelovale države članice na koje će se jednom Konvencija odnositi, već ju je pripremala „stručna skupina“, a države su preko Vijeća ministara mogle samo prihvatiti ili ne prihvatiti finalni tekst.

U samom svom tekstu (čl. 78) Konvencija zabranjuje rezerve na sve one članke koji bi mogli rezultirati navedenim neželjenim posljedicama za društvo i pravni poredak. Tako, nažalost, nije moguće ratificirati (samo) dobre dijelove Konvencije stavljajući rezerve na sporne dijelove. Zbog toga je, za nas i naše podneblje, bio farz odbiti ovu Konvenciju u potpunosti!

\section{COMING OUT}

Coming out kao pojedinačnog, personalnog predstavljanja lične homoseksualnosti njihovi promotori definiraju na sljedeći način:

"Coming out (eng. coming out of the closet - izlazak iz ormara) predstavlja doživotni proces istraživanja sopstvene homoseksualnosti, uključujući dijeljenje $i$ razmjenu tog iskustva sa porodicom, prijateljima i prijateljicama, kolegama i kolegicama na poslu, u školi, ali i sa širom društvenom zajednicom (Vučaj 2009). Ovo je centralno pitanje u životu svake LGBT osobe. Sam coming out predstavlja proces koji najprije podrazumijeva otkrivanje i prihvatanje sopstvene homoseksualnosti/biseksualnosti, a tek nakon toga i saopštavanje drugim osobama.",16

"Coming out zapravo znači složeni proces prepoznavanja, prihvatanja, izražavanja i dijeljenja svoje seksualne orijentacije s drugima kao i sa sobom. To je lični i društveni proces u kome se osoba kreće od suočavanja preko prihvatanja do saopštavanja svoje seksualne

${ }^{16}$ Čitanka LGBT ljudskih prava, Uvod, 15. 
orijentacije. Termin coming out se pojavio početkom dvadesetog vijeka. Dolazi iz engleskog jezika, te se u našem jeziku počeo koristiti u skraćenom obliku. Prvobitno se koristio termin coming out of the closet, što u bukvalnom prijevodu znači izlazak iz ormara, te predstavlja prestanak skrivanja i početak prihvatanja i saopštavanja seksualne orijentacije sebi i drugima."17

\section{PRAJD/POVORKE PONOSA}

Što se tiče povorki ponosa kao kolektivnog, organizovanog predstavljanja osoba homoseksualne orjentacije i njihovog izlaska $\mathrm{u}$ javnost oni ih pravdaju i objašnjavaju:

"Ponos ovdje, prije svega, predstavlja ponos zbog hrabrosti u borbi za svoja prava, kao i odgovor na omalovažavanje patrijarhalne zajednice, a ne ponos zbog seksualne orijentacije kao takve - ona naprosto varira od osobe do osobe i nema nikakvu a priori negativnu ili pozitivnu vrijednost. Na ovim prostorima još uvijek nema "gej parade" u tom obliku, jer je to specifično zapadno iskustvo, nastalo u posebnim historijskim okolnostima, dugo razvijano i mijenjano. Za sličan događaj ovdje još uvijek nema uslova, zbog nerazvijene LGBT potkulture/ infrastrukture (u odnosu na zapadnu) do ekonomskih problema (pitanje komercijalne isplativosti). Međutim, protestno okupljanje kao obilježavanje Dana ponosa ovdje ima prije svega politički značaj. Drugo, koristi se elementarno pravo, zagarantirano Ustavom, na slobodno okupljanje i protest, protest koji ima za cilj da naglasi da je diskriminacija prema LGBT osobama i dalje prisutna, tražeći njeno ukidanje. Treće, sama manifestacija je dio procesa borbe za ravnopravnost LGBT populacije." 18

Od 1970. godine, Povorka ponosa postaje jedna od najvažnijih političkih aktivnosti pokreta homoseksualnosti koja se organizira širom svijeta, obično u junu ili julu. Cilj Parade ponosa je izazivanje, provociranje i preispitivanje ustaljenih matrica vrijednosti, borba protiv navodne diskriminacije, ukazivanje da su u društvenoj zajednici prisutne LGBT osobe i njihovo favorizovanje u odnosu na većinsku

\footnotetext{
${ }^{17}$ Čitanka LGBT ljudskih prava, Homofobija i coming out, 224.

${ }^{18}$ Čitanka LGBT ljudskih prava, Parade ponosa - Uvod - 20.
} 
heteroseksualnu populaciju. Kada većinska populacija istupa protiv ovakvog vida prezentacije u javnom prostoru tražeći da to bude privatna stvar i izbor (u četiri zida) onda se takvi zahtjevi i istupi osuđuju kao homofobni, a politika i država se instrumentalizuju pod medijskom propagandom i pod dejstvom svjetskih lobija da to metodom mrkve i štapa, tj. represijom, snajperima, policijom, vojskom, nasilu održi direktno služeći na taj način u senzibiliziranju javnosti za homoseksualnost i njenu ideologiju.

\section{HOMOSEKSUALNOST U SVJETLU ISLAMA}

Nema spora $\mathrm{u}$ islamskom pravu da je promocija homoseksualnosti delikt protiv čovječanstva, vjerskih i tradicionalnih vrijednosti, a njegova agresivna javna ideologizacija kroz LGBTIQ kulturu i pokret diskriminira ogromnu većinu čovječanstva.

Islam je historijski prva istinska ideologija koja je priznala različitost tekstom najviše pravne snage: (la ikrahe fid-din - nema ideološke prisile), ali isto tako odbila je tuđe ideološko nametanje (lekum dinukum ve lije din - vama vaše uvjerenje a meni moje).

Netom održana Parada ponosa u Sarajevu pod krinkom zaštite ljudskih prava nastavak je aktivnosti u daljnjoj promociji i društvenopravnoj zaštiti i nametanju LGBTQ ideologije na prostorima Balkana.

Pravno i društveno utemeljenje ove ideologije na našim balkanskim prostorima pa i u $\mathrm{BiH}$ snažno započinje spomenutom Istanbulskom konvencijom i evo nastavlja se kroz coming out i Parade ponosa do uvođenja te ideologije i njene prakse u naše društvo kroz raznorazne institucije: političke, pravne, društvene, vjerske, obrazovne, sportske, zabavne itd.

Ako se u našem društvu, zbog indolentnosti svih onih koji bi trebali reagovati i njihovog neshvatanja dubine ovog problema, pusti ovoj agresivnoj ideologiji njen javni prozelitizam, kojeg štite njihovi bjelosvjetski sljedbenici, ambasadori i ambasade najjačih svjetskih država, sve institucije pravne države kroz društvene, političke i posebno pravne institucije, s ovom indolencijom i našim stalnim ponavljanjima kako nemamo ništa protiv tih nastranosti, sutra očekujmo zakonsko prisiljavanje vjerskih službenika na "šerijatska homoseksualna vjenčanja”, predškolske, mektepske, školske, nastavne, fakultetske, 
homoseksualne obrazovne programe, sportske, zabavne i druge. Očekujmo da oni koji se ne slažu s tom ogavnošću, makar bili preko 90\% društva, budu procesuirani zbog nepoštivanja zakona koji su usvojeni ili će se usvojiti, "verbalnog delikta", navodnog ekstremizma, širenja govora mržnje i sl. Ekspresni poziv Muje Aganovića, predsjednika Saveza RVI paraplegičara Federacije Bosne i Hercegovine, na informativni razgovor istog dana kada je održana sarajevska parada, egzemplaran je primjer za to.

Nedostojno je čovjeka, vjernika ili ateiste, da se u svjetskim globalnim razmjerama pod krinkom demokratije i zaštite ljudskih prava i raznih nastranosti, devijacija i društvenih bolesti ide ka uništenju porodice i promjeni božanske antropologije kod savremenog tretmana čovjeka kao što se čini spomenutim aktivnostima i primjenom sporne Istanbulske konvencije.

Trebalo se i treba svim zakonski dozvoljenim sredstvima boriti protiv neprijateljske ideologije i njenog delikta prema čovječanstvu koja bi, kod striktne primjene, uništila ljudski rod u jednoj generaciji.

Potpisivanjem i ratifikacijom Konvencije dolazi se u situaciju da će sveštenici, odnosno imami, dolaziti u nezavidnu zakonsku situaciju kod primjene. Naime, kako će reagovati neki sveštenik kada mu dođe Jovo i Marko, dvojica muškaraca ili mu dođe Marija i Janja dvije žene i kažu: -Vjenčaj nas!

Ili kako će reagovati imam ili muftija kada mu dođe Suljo i Mujo, dvojica muslimana po imenu i kažu: - Vjenčaj nas! Ili Fata i Haša, dvije muslimanke po imenu!

Hoće li svi oni odbiti to izlažući se optužbi za diskriminaciju, ekstremizam, govor mržnje jer njihovo odbijanje predstavlja pravno protivljenje najvećem usvojenom pravnom aktu u zemlji?!

Jer kada se potpiše i ratificira Konvencija, (što se već desilo) to je najviši pravni akt i to se, onda, ne smije odbiti, zarad vjere, tradicije, običaja i drugih "predrasuda"!!!

Kako će vjeroučitelj reagovati kada mu dijete usvojeno od istospolnih partnera u razred donese rezultate rodne ideologije kroz slikovnice, slike i knjige gdje se promovira brak i sloboda homoseksualnih veza?! 
Ili imam kada mu se to desi u mektebu? To su sve pitanja, bez pravog odgovora, za vjernike i IZ BiH.

\section{DUNJALUČKA (OVOSVJETSKA) I AHIRETSKA (ESHATOLOŠKA) KAZNA ZA SEKSUALNE PERVERZIJE}

Cilj javnog prezentovanja LGBT pokreta i ideologije je nametanje homoseksualne kulture u glavnim društvenim strujanjima metodom coming outa i paradama ponosa, te zastrašivanje i ušutkavanje onih koji se protive njihovim željama. Njihov krajnji cilj je promijeniti svjetonazor društva i utrti put dovođenja homoseksualnog pokreta do društvene moći i tretmana homoseksualnog ponašanja kao "prava" za koje se legitimno treba boriti kroz pokret i strategiju koja homoseksualno ponašanje može predstaviti i "prodati" kao pitanje građanskih ili ljudskih prava, a one koji se protive tome optužiti kao "neupućeno i homofobno društvo". Takve optužbe, posebno kada se usvoje "specijalne" zakonske odredbe su u ulozi batine za ušutkavanje neistomišljenika, nešto slično kao što je bila uloga Inkvizicije služeći Crkvi ili Gestapoa služeći Hitleru.

\section{KAZNE ZA JAVNI RAZVRAT}

Gledajući s islamskog aspekta javna promocija nezakonitog ponašanja i posebno javnog razvrata i perverzije je apsolutno neprihvatljiva $\mathrm{i}$ podliježe ovosvjetskim oštrim sankcijama ili u krajnjoj konsekvenci ahiretskim kaznama.

Iz mnogobrojnih kazivanja o prošlim narodima u Kur'anu su spomenute ovodunjalučke kazne za neke bestijalnosti i izopačenosti koje su bile javne i neskrivene, zbog kojih su uništeni čitavi prijašnji narodi $u$ strašnim apokaliptičnim kaznama ili smrtnim bolestima koje su ih kolektivno pogađale. Bilježe Ibn Madže, Bejhekija i Bezzar od Ibni Omera, r.a., a i Hakim od Burejde vjerodostojno predanje, po kriterijima Muslima, u kojem se kaže:

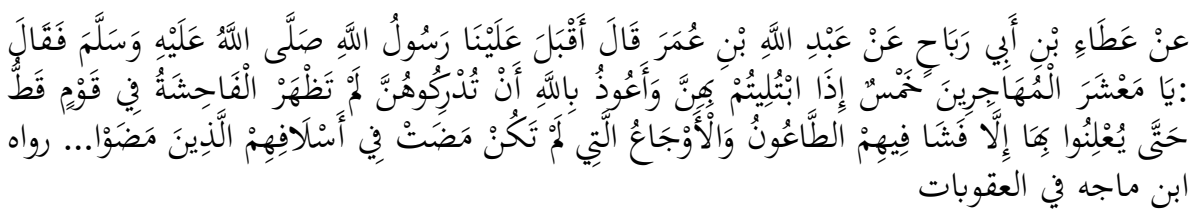

Došao nam je Allahov Poslanik, a. s., i rekao: 
Muhadžiri! Sa pet svojstava, ako se nađu pri vama, bićete iskušani, - a ja se utječem Allahu moleći Ga da vi to ne dočekate:

Nikada se neće pojaviti razvrat u nekom narodu koji ga bude javno činio a da se paralelno s tim ne prošire razne bolesti, potpuno nepoznate ranijim, prošlim generacijama... ${ }^{19}$

U verziji ovoga predanja koje bilježi Malik, a smatra ga vjerodostojnim Ibn A'bdul-Berr, navodi se:

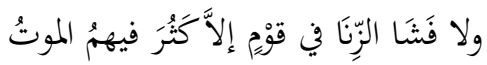

Niti će se proširiti blud u nekom narodu, a da se paralelno s tim ne proširi i poveća smrtnost. ${ }^{20}$

Razvrat, spomenut u hadisu, islamski učenjaci prokomentirali su bludom, prostitucijom, homoseksualnom orijentacijom i drugim vidovima perverzije koja se javno i bestidno upražnjava.

U današnje vrijeme svi smo svjedoci da se to javno dešava, da je to zapadna realnost već dugo vremena, ali da je sve više i naša svakodnevnica gdje kroz vrata parada ponosa i coming outa homoseksualnih osoba traži svoju javnost i priznavanje.

\section{PRAKTIČNI, ANKETOM POTVRĐENI PRIMJER OVOSVJETSKE KAZNE ZA JAVNI RAZVRAT}

Iz kur'anskih kazivanja saznajemo da su se dešavale i ostvarivale ovosvjetske kazne kompletnim narodima za neprirodne, homoseksualne nastranosti kao što je bilo apokaliptično stradanje Lutovog naroda. Iz prvog dijela hadisa kojeg smo citirali, a odnosi se na javni razvrat, vidimo da se kazna najavljuje i na ovom svijetu:

Nikada se neće pojaviti razvrat u nekom narodu koji ga bude javno činio a da se paralelno s tim ne prošire razne bolesti, potpuno nepoznate ranijim, prošlim generacijama... ${ }^{21}$

19 Zekijjud-din El-Munziri, Et-Tergibu vet-terhibu minel-hadisiš-šerif, (Muessesetuttarih vet-turasil-arebi, 1968), 2, 568.

${ }^{20}$ Ibid, 569.

${ }^{21}$ Zekijjud-din El-Munziri, Et-Tergibu vet-terhibu minel-hadisiš-šerif, (Muessesetuttarih vet-turasil-arebi, 1968), 2, 568. 
Niti će se proširiti zinaluk (prostitucija) u nekom narodu, a da se paralelno sa tim ne proširi i poveća smrtnost. ${ }^{22}$

Razvrat i njegovo javno manifestovanje sigurno je predmet prijetnje o navještenoj kazni iz pomenutog hadisa i kur'anskih kazivanja o ranijim narodima.

Pa da li se isto tako i kazna za to ostvaruje ovosvjetski/dunjalučki?! Ili je to samo mitska, vjerska prijetnja?!

Uzet ćemo životni primjer za koji smo našli neke statističke podatke u dnevnoj štampi na kojima možemo izvesti komparaciju i korisne zaključke, a odnosi se na jedan aspekt koji je naglasio Allahov Poslanik, s.a.v.s., kroz hadis kao vid navješćenja i predskazanja koje se ostvarivalo kroz historiju pa i u našem vremenu. Ustvari, ovo je nadnaravnost kojom je nadahnut Allahov Poslanik, a.s., i za svakog pametnog, realnog pragmatika, kada danas posluša ono što je govorio i na šta je pozivao prije više od 14 vijekova, može sa sigurnošću utvrditi da to nije mogao znati čovjek onoga doba, nego samo onaj koji je nadahnut od Svevišnjeg Boga...

Iz jedne novinske ankete ${ }^{23}$ koja je rađena u Hrvatskoj razumije se da je vid kazne već stigao. Naime, seksualna izopačenost, koja se realno dešava u društvu, a iskristalizirala se u spomenutoj anketi (radi se o vidovima izopačenosti koje je islam strogo zabranio), sigurno je prouzrokovala da tek $27 \%$ osoba, iz nekih područja obuhvaćenih anketom, ili tek $9 \%$, iz nekih drugih, doživljava zadovoljstvo u bračnim odnosima.

Zamislite koji je procenat onih koji su prikraćeni za najljepše dunjalučko zadovoljstvo u braku? I koji su, onda, stimulansi izgubljeni

\footnotetext{
${ }^{22}$ Ibid, 569.

${ }^{23}$ Do ruku mi je dospjelo jedno javno istraživanje - anketa o seksualnom životu 1000 ispitanika (žena i muškaraca) u susjednoj Hrvatskoj čiji su rezultati i zaključci javno objavljeni u sredstvima javnog informisanja.

U toj anketi se navodi, između ostalog, da $40 \%$ ispitanika opći u analni otvor; $2 \%$ opći sa životinjama; svaka deveta žena, u nekim područjima obuhvaćenih anketom, ili čak svaka šesta u drugim područjima, ima iskustva s osobom istog spola; vanbračni odnosi su gotovo normalni i dostižu procenat od $46 \%$ u pojedinim ispitanim područjima i sl. (Vidi: Nacionalni tjednik, Globus, br: 702, 21. 5. 2004.)
} 
da se brak, uopće održi, a time i porodica, odnosno reprodukcija čovjeka? U nekim drugim područjima $24 \%$ ispitanika rijetko doživljava to zadovoljstvo ili gotovo nikada.

Seksualno uživanje u braku kod normalnih ljudi je jedno od najvećih dunjalučkih ni'meta i uživanja. Ako je to tako, onda je i prikraćivanje tog uživanja jedan vid strašne kazne. Dakle, jedno od najljepših dunjalučkih uživanja velikom procentu ispitanika ankete je prikraćeno. Uzvišeni Allah im je oduzeo to uživanje. Zar to, samo po sebi, nije strašna kazna?!

A da ne govorimo o zastrašujućim spolnim bolestima koje se javljaju kao dunjalučka kazna i odgovor na seksualne izopačenosti.

Ona je navještena i obećana na jeziku Allahovog Poslanika, s.a.v.s., prije 1400. g. jer nove nepoznate bolesti, o kojima govori spomenuti hadis, savremeni učenjaci između ostalog tumače da se odnose na spolne bolesti kao što su sida i druga savremena aktualna virusna oboljenja koja nisu bila poznata ranijim generacijama. ${ }^{24}$

Naravno, ovim izrečenim proročanstvima Allahovog Poslanika, a.s., nije potreban nikakav drugi komentar. Dovoljno je da se imaju zastrašujuće informacije o oboljelima od side i o progresivnoj smrtnosti onih kod kojih je došlo do inficiranja i zaraze uzrokovane nemoralom i razvratom.

Iz ovako egzemplarnih primjera možemo zaključiti da je islam kao vjera, religija i Šerijat kao njegov pravni sistem, nadnaravnog, božanskog karaktera. Ta karakteristika ga odlikuje nad svim ostalim ljudskim sistemima i porecima.

Zar mogu ljudi ustrojiti nešto kao što to ustroji Bog?! Nikako!

Zato muslimani trebaju biti posebno ponosni što su sljedbenici islama $\mathrm{i}$ ne padati u stanje inferiornosti ili kompleks niže vrijednosti iz razloga što su politički i vojno potlačeni, medijski okvalifikovani kao teroristi i

${ }^{24}$ O ovoj temi sa šerijatskog aspekta i spolnim bolestima od kojih su: sida, klamidija N. G. U., gonoreja N. G. D., sifilis i druge bolesti, pogledaj u knjizi Spolne bolesti dr. Muhammeda Ali el-Barra u izdanju Visokog saudijskog komiteta za pomoć BiH, Sarajevo, 1998. 
pribijeni na zid srama pod stalnom, nesmiljenom medijskom harangom i meta jakih svjetskih neprijatelja.

Muslimani su specifični, razlikuju se od drugih po svojim vrijednosnim sistemima i ponosni kao pripadnici vjere koja je došla od Vladara i Kreatora kosmosa.

Kada se drže vjere, koja kako vidjesmo na ovim jednostavnim primjerima, može biti samo od Boga, onda su najbolji narod koji se pojavio na ovoj zemaljskoj kugli.

Uzvišeni Allah to svjedoči kada kaže u Kur'anu:

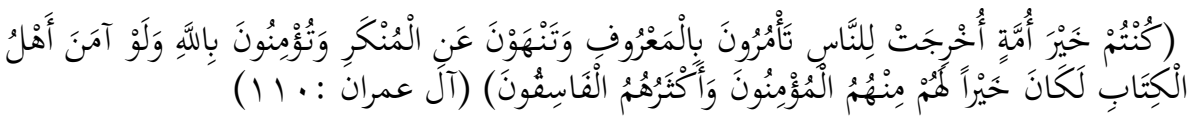

Vi ste najbolji narod koji se ikada pojavio: tražite da se čini dobro, a odvraćate od zla, i vjerujete u Allaha! A kada bi sljedbenici Knjige vjerovali, bilo bi bolje za njih; među njima ima vjernika, ali-većinom su grješnici! (Kur'an, 3: 110)

Isto tako, idući logikom argumentuma a contraria, iz kontra logike ajet upućuje na to da onaj ko se ne drži vjere, ne traži da se čine dobra djela, od loših djela ne odvraća i u Allaha ne vjeruje, spada u najgore ljude.

\section{KUR'ANSKI PRIMJER OVOSVJETSKE, KOLEKTIVNE KAZNE ZBOG JAVNOG GRIJEŠENJA}

Ovdje ćemo navesti kroz hermeneutiku Kur'ana i njegovog kazivanja jednu posebnu, specifičnu kaznu koju su doživjeli Izraelićani za jedan, također, poseban, jedinstven način griješenja. Naime, oni su zbog pokušaja hile, nadmudrivanja Allaha, dž.š., i izigravanja Njegovih propisa, egzemplarno i drakonski kažnjeni jedinstvenom neponovljivom kaznom na ovom svijetu.

U Kur'anu se navodi primjer drevnog židovskog naroda koji se služio trikovima i hilama u pokušaju preinačavanja prirode zabranjenih djela „čineći ih dozvoljenim” pa su zbog toga kažnjeni neuobičajenom, strašnom kaznom pretvaranja u majmune.

Vama je poznato ono što se dogodilo onima od vas koji su se o subotu ogriješili, kao $i$ to da smo im Mi rekli: ,Budite majmuni prezreni!' (Kur'an, 2: 65) 
Iz hermeneutike ovoga ajeta saznajemo da su židovi odbili dan džume, kao odabrani praznični dan, tražeći umjesto njega da to bude subota. Petak je bio obavezan praznični dan za sve narode prije židovskog kroz historiju, kao i za muslimane poslije njih. Pošto su oni odbili petak insistirajući da praznik bude subotom, onda ih je Allah, dž. š., iskušao nečim što im je inače dozvoljeno, tj. zabranom lova $\mathrm{i}$ jedenja ribe na dan svetkovanja. Međutim, jata velikih riba (kitovi), Allahovom odredbom, dolazila su do obale samo subotom. Dakle, ribe je bilo u izoblju odabranim neradnim danom kada je židovima bilo zabranjeno loviti i jesti ribu. Drugim, radnim danima kada su smjeli loviti, ribe nije bilo ni za lijeka. Povlačila se negdje na pučinu tako da je više nisu ni viđali do subote.

U Kur'anu se kaže: I upitaj ih o gradu koji se nalazio pored mora kad su propise o suboti kršili: kad su im ribe, na oči njihove, dolazile dok su subotu svetkovali, a kad nisu svetkovali one im nisu dolazile. Eto, tako smo ih u iskušenje dovodili zato što su stalno griješili. (Kur'an, 7: 163)

$\mathrm{Na}$ koncu nisu izdržali iskušenje pa su počeli pojedinačno smišljati trikove kako da zadrže i love ribu subotom, a u isto vrijeme izbjegnu skrnavljenje zabrane lova. Praktično je to započelo u naselju Medjena kada je neki čovjek ulovio kita subotom, svezao ga za kolac poboden na obali, a zatim pustio u vodu. U nedjelju ga je izvadio i ispržio. Tom hilom je htio izigrati propis zabrane lova subotom. Tako je učinio i sljedeće subote. Komšiluk je osjetio miris pržene ribe i taj trik se otkrio. Tako su i ostali počeli s istim poslom ,tajno" i to je trajalo dugo vremena. Allah, dž. š., ih nije kažnjavao sve dok to nisu počeli javno raditi i javno prodavati ulovljenu ribu na tržnici.

Drugi se poslužio još originalnijim trikom. Iskopao je rupu na obali do koje je prokopao kanal. Za vrijeme plime valovi bi donijeli ribu u tu rupu. Kada bi se voda povukla kanalom, riba bi ostajala zarobljena i ne bi se mogla vratiti na pučinu.

Iz kur'ansko-sunnetskih normi, a i iz iskustva, zna se da Allah, dž.š., ne trpi javno griješenje i pregonjenje u griješenju i zulumu (nasilje). Kada ono postane opće, javno griješenje na ulici, bez stida i bojazni od kazne, i kada se izgubi nada u popravljanje i kajanje, onda Allah, dž.š., interveniše s dunjalučkom, kolektivnom kaznom koju spusti na griješni 
narod u vidu raznih katastrofa, kataklizmi, nepoznatih bolesti i sl., kako bi ih usmrtio, a onda bi se iza toga nastavila i eshatološka kazna.

U predmetnom slučaju kada je kršenje zabrane postalo javno i masovno, njihova ulema ih je počela upozoravati na grijeh zabranjujući im takve trikove. Židovi su odbili da prestanu s lovom braneći se kako love i vade ribu iz vode nedjeljom tj. dozvoljenim danom.

Oni koji nisu činili taj grijeh podijelili su se na dvije grupe: opominjači i neutralci. Neutralci su govorili kako to Kur'an bilježi:

A kad neki od njih rekoše: „Zašto opominjete narod koji će Allah uništiti ili ga teškim mukama namučiti?" - oni odgovoriše: „Da bismo se pred Gospodarom vašim opravdali $i$ da bi se oni grijeha klonili. “ (Kur'an, 7: 164)

Nakon toga su se podijelili. Vjernici su se odvojili u jednom dijelu naselja pregradnim zidom i posebnim gradskim vratima ne mješajući se sa onima koji nisu svetkovali subotu. Davud, a. s, ih je prokleo. Kur'an dalje konstatira:

I kad zaboraviše ono čime su bili opominjani, Mi izbavismo one koji su od nevaljalih djela odvraćali, a teškom kaznom kaznismo grešnike, zato što su stalno u grijehu bili. I pošto su oni bahato odbili da se okane onoga što im se zabranjivalo, Mi smo im rekli: „Postanite majmuni prezreni!" (Kur'an, 7: 165-166)

Jedno jutro vjernici su izašli van, međutim, nevjernici nisu otvarali svoja vrata. Popeli su se na zid i ugledali ih pretvorene u majmunski čopor. Otvorili su im vrata i oni su se razišli po zemlji.

U sažetku tefsira (komentara) Ibn Kesira spominje se da su židovi istinski pretvoreni u majmune i nisu živjeli poslije toga više od tri dana, ne jedući, ne pijući i seksualno se ne približavajući ženkama.

U hermeneutici ovoga ajeta spominje se i mišljenje Mudžahida koji smatra da je ajet metafora o pretvaranju židova u majmune.

Dakle, u ovom kur'anskom primjeru vidimo da se lukavštinom i trikom, inoviranjem i preimenovanjem ne mijenja status i priroda zabranjenog djela, nego naprotiv, i pokušaj toga kažnjava se najstrožijom kaznom. Naravno, to što su židovi lovili u zabranjeni dan i prolijevali riblju krv 
nije bio veći haram od prolijevanja ljudske krvi i krvi poslanika koje su ubijali, te krvi palestinskih civila, djece žena i staraca.

Pa ipak, Kur'an obavještava da je Allah, dž.š., požurio s ovosvjetskom kaznom prvih, pretvarajući ih u majmune, dok je drugima odložio kaznu za budući svijet. Međutim, u tome ima simbolike. Židovi koji su činili taj prijestup bili su sljedbenici Tevrata (Tore) pretvarajući se da slušaju i poštuju njegove norme, iako su ustvari činili prekršaj. Taj pokušaj izigravanja propisa samo je ličio na pokornost i poštivanje normi, a u biti je bio nedozvoljen čin. Zato je i kazna bila primjerena $\mathrm{i}$ ekvivalentna tome. Pretvoreni su u majmune koji samo liče na ljude, a u biti nisu kao ljudi.

\section{STAV ISLAMA PO PITANJU HOMOSEKSUALNOSTI}

Monoteističke religije svijeta, homoseksualne odnose proglašavaju razvratom i neprirodnim činom, te ih kao takve najoštrije osuđuju i sankcionišu, mada postoje i neke kršćanske crkve koje ne osuđuju homoseksualnost, prvenstveno iz razloga što su se duboko u njih integrisali homoseksualci i njihovi lobiji tako da je i sam Papa izrazio pesimizam u pogledu reforme Kurije zbog postojanja gay lobbiya ${ }^{25}$.

Uzvišeni Allah kategorički zabranjuje homoseksualne odnose i predstavlja ih kao veliki grijeh, neprirodno ljudsko stanje i zločin koji degradira i ugrožava život, razvratno, gnusno djelo i prelaženje svake granice normalnosti.

Uzvišeni sa gnušanjem govori o Lutovom narodu:

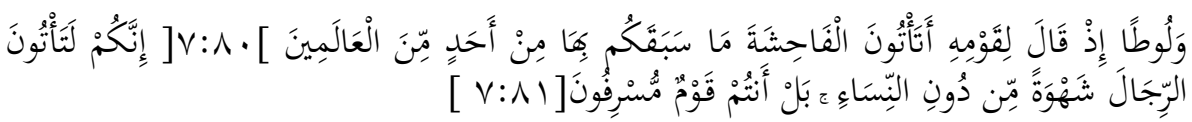

I Luta - kad reče narodu svome: "Zašto činite razvrat koji niko prije vas na svijetu nije činio? Vi sa strašću prilazite muškarcima, umjesto ženama. Ta vi ste narod koji sve granice zla prelazi!" (Kur’an, 7: 81)

I obavještava u suri Hud kako je zbog toga skončao taj narod:

\footnotetext{
${ }^{25}$ Papa Frane: Postoji 'gay lobby' u Rimskoj kuriji - sam ne mogu provesti reform http:/www.slobodnadalmacija.hr/Svijet/tabid/67/articleType/ArticleView/articleId/2 12730/Default.aspx, posjećeno, 29. septembra 2019
} 


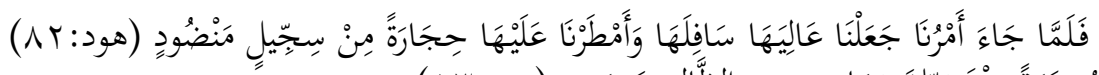

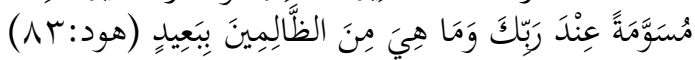

I kada pade naredba Naša, Mi sve prevrnusmo, ono što je gore - bi dolje, i na njih kao kišu grumenje od pečena blata spustismo, koje je neprekidno sipalo, obilježeno od Gospodara tvoga , - a ono nije daleko ni od jednog nasilnika. (Kur'an, 11: 82-83)

\section{PRIJESTUP HOMOSEKSUALNIH RADNJI NA VAGI ŠERIJATA}

Iako postoji konsenzus islamskih pravnika i učenjaka o sankcioniranju homoseksualnih odnosa, ipak postoji razilaženje po pitanju pravnog osnova i pravne sankcije za ovaj prijestup gdje se mogu navesti četiri divergentna stava:

1. Prijestup homoseksualnih odnosa zaprijećen je smrtnom kaznom, generalno, s tim da se razilaze kojom konkretnom sankcijom se to izvršava. Ovaj stav se vezuje za grupu ashaba i tabiina, malikije, ${ }^{26}$ to je i Stari mezheb Šafije, ${ }^{27}$ mada se prenosi i njegov Novi mezheb u vidu kvalifikacije homoseksualnog griješenja identične bludu, jedan stav i jedan rivajet imama Ahmeda, ${ }^{28}$ preferirani stav Ibn Tejmije, ${ }^{29}$ i Ibnul-

\footnotetext{
${ }^{26}$ El-Badži, Ebul-Velid, Sulejman b. Halef, El-Munteka, šerhu-Muvetta Malik, (Bejrut:darul-kutubil-i'lmijje), 7,141, Ibnul-A'rebi, Ahkamul-Kur'an. (Darul-kutubili'lmijje, 2003.), 2,318, Ahmed b. Muhammed El-Emin b. Ahmed, Mevahibul-Dželil min edilletil-Halil (Katar: Idaretu ihjait-turasil-islamim 1983.), 6, Ahmed b. Ganim, Šihabud-din En-Neferavi, El-Fevakihud-devani, (Bejrut: Darul-kutubil-i'lmijje), 2,210 .

${ }^{27}$ Muhammed b. Idris eš-Šafi' i, El-Umm, (Libanon, Bejrut: Daru-l-ma'rife), 7/139.

${ }^{28}$ Ibn Kudame, Eš-Šerhul-kebir a'lel-Mukni'i, (Darul-kutubil-A'rebi litt-tevzi'i vennešr, 2010.), 26,272, Ibn Kudame, Abdul-Muhsin Et-Turki i dr. Abdul-Fettah El-Hilv, El-Mugni, (Kairo: Hidžr, 1992.), 9/59.

${ }^{29}$ Ibn Tejmije, Es-Sijase eš-šer'ijje fi islahir-ra'i vere'ijje, (Daru a'lemil-fevaid, tahkik: Ali b. Muhammed), 133, Ibnu Tejmijje, El-Fetaval-kubra, 3,413.
} 
Kajjima, ${ }^{30}$ Stalnog vijeća za fetve, ${ }^{31}$ Ibni Baza, ${ }^{32}$ Ibn U'sejmina ${ }^{33}$ i neke druge savremene uleme.

2. Prijestup homoseksualnih odnosa tretira se bludom i na njih se primjenjuje poznata kazna bluda (kamenovanje ili bičevanje u odnosu na prijestupnike da li su kategorije ženjenih ili ne). Ovaj stav ima grupa ashaba i tabiina, zatim Ebu Jusuf i Muhammed b. el-Hasen u hanefijskom mezhebu, ${ }^{34}$ to je i Novi mezheb Šafije, ${ }^{35}$ kao i potonji mezheb hanbelija. ${ }^{36}$

3. Počinitelji ovog krivičnog djela kažnjavaju se kaznom iz domena diskrecionog prava sudije. To je stav Ibrahima en-Nehaija, Ebu Hanife, ${ }^{37}$ koji smatra da je na sudiji u aktualnom trenutku da za taj prijestup dosudi i smrtnu kaznu u slučaju da se prijestup ponavlja i zahirija (bukvalisti). ${ }^{38}$

30 Ibn Kajjim El-Dževzijje, Ed-Dau ved-devau, (Daru a'lemil-fevaid, tahkik: Muhammed Edžmel), 409, Ibn Kajjim El-Dževzijje, Revdatul-muhibbin ve nuzhetulmuštakin, (medžmeu'l-fikhil-islami bi Džidda), 365.

${ }^{31}$ Fetaval-Ledžne, 22,53, El-Levat, mevkiu el-eimetis-selase, www.alaemmah.com > fatawa-details, posjećeno 25. septembra, 2019.

${ }^{32}$ Ibid, Ibnu Baz, Medžmu'u fetava ve mekalatin mutenevvia, 22,410.

${ }^{33}$ Muhammed b. Salih El-U'sejmin, Eš-Šerhul-mumti'u, (Daru Ibni Dževzi), 14,242.

34 Ebu Bekr, Ahmed b. Ali El-Džessas, Ahkamul-Kur'an, (Daru Ihjailkutubila'rebijjeti, 1992.), 3/387, Es-Serahsi, Šemsud-din, El-Mebsut, (Bejrut: DarulMa'rifeti, 1989.), 9,78, El-Kasani, Bedaiu-s-sanai', 7,35, Nasirul-islam Er-Ramfevri, El-Binajetu šerhul-Hidajeti, (Darul-fikri, 1990), 5,263.

${ }^{35}$ Muhammed b. Idris eš-Šafi'I, El-Umm, (Libanon, Bejrut: Daru-1-ma'rife), 7,139, En-Nevevi, Minhadžu-t-talibin, 503.

${ }^{36}$ Ibn Kudame, Abdul-Muhsin Et-Turki i dr. Abdul-Fettah El-Hilv, El-Mugni, (Kairo: Hidžr, 1992.), 9/59, El-Buhuti, Keššaful-kina', (Matbe'atus-sunnetil-muhammedijje), 6,96, Mustafa b. Sa'd, Er-Ruhajbani, Metalibu ulin-nuhafi šerhi Gajetil-munteha, (Elmektebul-islami, 1989), 6,186.

37 Es-Serahsi, Šemsud-din, El-Mebsut, (Bejrut: Darul-Ma'rifeti, 1989.), 9,78, ElKasani, Bedaiu-s-sanai', 7,35, Nasirul-islam Er-Ramfevri, El-Binajetu šerhulHidajeti, (Darul-fikri, 1990.), 5,263, Ibn-Humam. Fethul-kadir šerhul-hidaje, (Matbe'atu Mustafa Muhammed bil-Kahira), 5,263.

${ }^{38}$ Ali b. Ahmed b. Hazm el-Endelusi, El-Muhalla bi-1-asar, (Liban, Bejrut: Daru-1kutubi-1-'ilmijje, 1988.) 12,392. 
4. Stav po kojem se objekat homoseksualnih odnosa sudi smrtnom kaznom dok se činilac i subjekt tretira kao bludnik. Ovaj stav se, po Ibni Hazmu vezuje za šafijskog učenjaka i pravnika Ebu Dža'fera Muhammeda b. Alija b. Jusufa. ${ }^{39}$

Prema ovim pravnim stavovima ova vrsta razvrata nikada ne može biti legalna i zakonita, te je kažnjiva u svakom slučaju i po svim stavovima uleme.

Kao što smo vidjeli, prijestup homoseksualnih odnosa tretira se bludom, po jednom fikhskom stavu, i na njih se primjenjuje poznata kazna za blud što je stav Ebu Jusufa i Muhammeda b. el-Hasena u hanefijskom mezhebu.

Da bi se sprovela fiksirana sankcija za blud (hadduz-zina) mora se nesumnjivo dokazati sa 4 vjerodostojna svjedoka, ili s priznanjem, ili sa sigurnom trudnoćom, ili sa nepostojanjem sumnje u silovanje ili otmicu.

Dakle, onaj ko zaniječe blud, gotovo da ne postoji način dokazivanja svjedocima, jer se za prihvatanje svjedočenja uslovljava da su svjedoci nesumnjivo vidjeli spolni ud muškarca penetriran u spolni ud žene. Ne uzima se u obzir ako bi svjedoci izjavili „kako su ga vidjeli golog na nagoj ženi“, ili kada bi izjavili ,da su ga vidjeli na njoj u aktivnosti kao što čini i čovjek sa svojom ženom“. To nije dovoljno za prihvatanje svjedočenja na sudu koje mora biti eksplicitno, tj. „da je viđen muški ud penetriran u ženski ud“, i da to bude jasno kao što je jasna svjetlost sunca, kako se navodi u hadisu: „Ako si vidio jasno kao sunce svjedoči, inače ostavi..." (Et-Taberani i Ed-Dejlemi)

Zbog praktične nemogućnosti da sva četverica svjedoka to tako vide, Ibn U'sejmin navodi riječi Ibn Tejmije: „Blud se nije potvrdio izjavom svjedoka od pojave islama do danas, nego priznanjem, jer je vjerodostojno svjedočanstvo u tome jako teško potvrditi... “40

Prema tome jasno je da coming out kao i parade ponosa u slučaju homoseksualaca i LGBT populacije na stepenu priznanja koje prouzrokuje, sankciju za razvrat kojeg je Uzvišeni zabranio:

\footnotetext{
${ }^{39}$ Ibid, 12,392.

${ }^{40}$ Muhammed b. Salih El-U'sejmin, Eš-Šerhul-mumti'u, (Daru Ibni Dževzi), 14,257.
} 


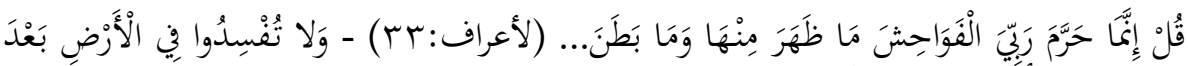

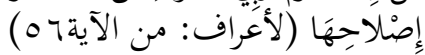

Reci: Gospodar moj zabranjuje razvrat, $i$ javni $i$ tajni, $i$ grijehe... (Kur'an, 7: 33), I ne pravite nered na Zemlji, kad je na njoj red uspostavljen”. (Kur'an, 7: 56)

Međutim, Uzvišeni zabranjuje i uhođenje i kršenje svetosti kućne intime tako da se taj razvrat ne može sankcionirati ako je u ,četiri zida“ i ne krši javni red, jer Uzvišeni naređuje: ... I ne uhodite jedni druge ...! (Kur'an, 49: 12)

Prema tome svrha propisa svjedočenja je da se blud i druge nevaljalštine ne čine javno! To ne znači da se za njih neće odgovarati iz razloga što to svjedoci ne mogu pravovaljano posvjedočiti! Kazna će doći ovosvjetski ili eshatološki.

Iako u osnovi sve značajnije svjetske religije osuđuju homoseksualno djelovanje, primjetno je da su spomenuti centri moći uspjeli i određene vjerske zajednice prisiliti da svoje izvorne kritičke stavove naspram homoseksualnosti u velikoj mjeri korigiraju, pa čak i potpuno promijene.

Zbog svega spomenutog, postoji potreba da se šira društvena zajednica sistemski upoznaje s negativnom suštinom pojave homoseksualne ideologije i pogubnim posljedicama koje ona sa sobom nosi.

Zasigurno će tema homoseksualnosti, njene supkulture, zaštite i/ili diskriminacije i u narednom vremenskom periodu biti sve više aktuelna, jer će se ta pitanja pozicionirati i u zakonodavne, parlamentarne vode gdje će lobiranjem, obmanama i pritiscima tražiti specijalne propise i zaštitu tako da je davno prošlo vrijeme neutralnosti i indolentnosti, posebno onih koji budu imali određene odgovornosti, jer će se od njih tražiti podrška, jasan stav i određenje.

\section{ZAKONSKI OKVIR I SAVREMENE PROMJENE U GLEDANJU NA PORODICU I BRAK}

Dakle, kod nas kao i u zemljama regiona, vidljiv je utjecaj međunarodne zajednice i njenih pravnih normi na lokalna zakonodavstva, kao i utjecaj politike i globalnih evroatlantskih integracija nametanjem novih zakonskih rješenja koja u nekim slučajevima zadiru u samu bit i srž 
dosadašnjih pravnih shvatanja i terminoloških određenja, protive se uvriježenim vjerskim i moralnim normama stanovništva, bez obzira na vjeru i naciju.

Općepoznati međunarodni akti koji su izvori porodičnog prava, preuzeti su gotovo bez ikakvih izmjena u zakonodavstvo zemalja našeg regiona/okruženja.

Porodica se u teoriji često definira kao osnovna ćelija društva i/ili kao jedna od najsloženijih društvenih grupa u našem zakonodavstvu i u međunarodnim i evropskim ugovorima i dokumentima. U ovim ugovorima normira se zaštita porodice, a konvencija o zaštiti ljudskih prava i osnovnih sloboda garantuje pravo na poštivanje porodičnog života kao jedno od osnovnih ljudskih prava. Međutim, svi su ovi ugovori doneseni prije sedamdesetih godina prošlog vijeka, a pošto je porodica sastavni dio društva, ona se mijenjala zajedno s njim, po zakonima koji određuju njegov razvoj.

Savremena definicija porodice odnosi se na "životnu zajednicu roditelja $i$ djece $i$ drugih krvnih srodnika, srodnika po tazbini, usvojilaca $i$ usvojenika, i osoba iz vanbračne zajednice ako žive u zajedničkom domaćinstvu."

Još su rimski pravnici dali definiciju braka smatrajući je vezom između muškarca i žene koja predstavlja životnu zajednicu. $\mathrm{Na}$ našim prostorima, u naučnim krugovima, bila je općeprihvaćena definicija V. Bakića u kojoj je brak priznata $i$ uređena zajednica jednog muškarca $i$ jedne žene, zaključen u svečanoj formi, po njihovom slobodnom pristanku, raskidiv samo u slučajevima predviđenim zakonom.

U našem porodičnom zakonu, Član 6. pojam braka se tretira kao zakonom uređena zajednica života žene i muškarca.

Obiteljski zakon Hrvatske na sličan način definira brak tretirajući ga životnom zajednicom žene i muškarca dok u pravnoj legislativi Srbije i RS, sklapanje braka, podrazumijeva: Različitost polova, izjavu volje $i$ nadležnost; tako da - Brak sklapaju dva lica različitog pola davanjem izjava volje pred matičarem. To je: Zajednica života.

Iz naše regulative, kao i legislative zemalja u okruženju razumije se da je zakonska definicija braka koncizna i kratka, a sadržava i izražava suštinu braka i bračnih odnosa koja se može svesti na to da je brak 
zakonom uređena zajednica, zasnivaju je dva lica različitog spola, i to je životna zajednica žene i muškarca.

Dakle iz regionalne porodične legislative uočljivo je da je brak odnos između muškarca i žene, ali se priznaje i vanbračna/izvanbračna zajednica te se regulira i izjednačava s bračnom zajednicom pravnim dejstvom koje prouzrokuje.

Prema tome, uvjet za postojanje braka je različitost spolova koja izražava komponentu braka i davno prihvaćenog načela monogamije. Sve definicije braka, od najstarijih do savremenih definiraju brak kao životnu zajednicu žene i muškarca.

Koliko se u ovom smislu dešava promjena u zadnjih nekoliko dekada možda najbolje govori savremena praksa i citat autorice udžbenika Bračno pravo kada zaključuje:

Teško je zamisliti, s obzirom na formalnosti pri zaključenju braka, odnosno, prisustvo matičara, svjedoka i javnosti, da bi moglo doći do zaključenja braka lica istog spola. ${ }^{41}$

Međutim, na početku prošle godine čitamo u sredstvima javnog informisanja $^{42}$ vezano za hrvatsku stvarnost i aktualnost: Udruga Vigilare je ministrici znanosti i obrazovanja Blaženki Divjak uputila otvoreno pismo u kojem traži da odgovori: hoće li dozvoliti ulazak slikovnice o tzv. istospolnim obiteljima u hrvatske vrtiće i škole; hoće li ravnatelji moći odbiti 'ovakvu donaciju' i hoće li njezino ministarstvo stati iza njih u potencijalnim tužbama za „diskriminaciju“‘?

Prema tome, za pretpostaviti je da će u vrlo bliskoj budućnosti temeljni član porodičnog zakona u kojem se navodi da je brak životna zajednica žene i muškarca biti predmetom izmjena u našem zakonodavstvu kao i zakonodavstvu regiona, na čemu će homoseksualni svjetski lobi sigurno insistirati kao uvjetu evroatlantskih integracija pod izgovorom i parolom zaštite ljudskih prava, demokratije i sl.

\footnotetext{
${ }^{41}$ Nerimana Traljić \& Suzana Bubić, Bračno pravo, (Pravni fakultet Univerziteta u Sarajevu, Sarajevo, 2007.), str.: 38.

42 https://direktno.hr/zivot/obitelj/vigilare-pisao-blazenki-divjak-hocete-li-dozvolitiulazak-vrtice-i-skole-slikovnicama-s-istospolnim-109079/, pristupljeno 4. janura 2018 .
} 
U savremeno doba mnoga ,napredna" zapadna zakonodavstva imaju intenciju da idu za dozvolom nastranosti i perverzija koja prate moralni pad zapadnog čovjeka. Time zapadna civilizacija narušava univerzalne porodične vrijednosti, moral, brak i instituciju braka koja je prirodni i normalni uvjet za opstanak čovjeka na zemlji i njegovu reprodukciju.

U Hrvatskoj je 2013. g. održan referendum na kojem su građani odlučili da u Ustav uđe odredba prema kojoj je brak životna zajednica žene i muškarca. Inicijativa koja je prikupljala potpise građana na temelju kojih je referendum raspisan među argumentima za unošenje definicije braka u Ustav navela je želju da se spriječi izjednačavanje istospolnih partnerstava i braka, posvajanje djece od strane istospolnih parova te nametanje izjednačavanja istospolnih partnerstava i braka kao društveno općeprihvaćene norme.

Referendum o ustavnoj definiciji braka održan u Hrvatskoj 2013. rezultirao je da su se na njemu državljani RH izjasnili kako žele da se $u$ Ustav Republike Hrvatske prenese definicija iz postojećeg Obiteljskog zakona, gdje je brak definiran kao zajednica žene i muškarca.

Međutim, u Hrvatskoj je donesen i zakon o istospolnim zajednicama, 2003. g. za vrijeme predsjednikovanja zemljom Stjepana Mesića, a Saborom Zlatka Tomčića.

Među argumentima protivnika unošenja definicije braka kao životne zajednice žene i muškarca u Ustav navodi se tvrdnja da ona otvara put diskriminaciji istospolnih i izvanbračnih zajednica.

\section{ZAKLJUČCI I PREPORUKE}

1. Pošto se nalazimo u multikulturalnom društvu sa sekularnim poretkom i uređenjem države želimo, odmah (ne odugovlačeći), ukazati na naš stav da su vrijednosti, s kojima dolazi božanski sistem islama, posebno u oblasti božanske antropologije, porodičnog i bračnog prava, od krucijalne važnosti za kompletno čovječanstvo. Zbog toga tražimo pravnu zaštitu tradicionalne porodice i braka, u konstelaciji apokaliptičkih, savremenih odnosa gdje su napadnute njihove univerzalne vrijednosti, dovedena $\mathrm{u}$ pitanje i sama opstojnost i reprodukcija čovječanstva. 
2. Pošto se kod LGBT pokreta radi o alternativnoj kulturi koja je oprečna svim objavljenim, monoteističkim vjerama i zbog nesporne činjenice da se apsolutna većina svjetske populacije protivi homoseksualnoj ideologiji, bez obzira na nametnuta zakonska rješenja, deklaracije i pravni status, užasavajući se njenih teških posljedica koje rezultiraju rušenjem tradicionalne porodice i temeljnih, univerzalnih, moralnih vrijednosti, pojavom raznih novih oboljenja nepoznatih $u$ prošlim vremenima koja prate ovu populaciju, depopulacijom, bijelom kugom i slično, slažemo se s onima koji tvrde da iza ovog pokreta i njegove kulture njihove društvene, političke i pravne afirmacije stoje neke svjetske 'elite' i određeni vrlo uticajni lobiji i centri moći (masonski, židovski, porno, farmaceutski, satanistički, džender i drugi), tako da su u stanju nametnuti svoju volju, demonstrirajući je afirmacijom i postavljanjem premijera nekih vlada, predsjednika država, direktora utjecajnih, jakih institucija itd.

3. Stajalište Tome Akvinskog o homoseksualnosti kod čovjeka, odražava religijski i tradicionalni, milenijski stav prema ovoj populaciji izražen kroz poimanje homoseksualnosti kao protuprirodnoj i protivnoj Božijim zakonima, goroj od preljube, incesta i silovanja jer čovjek nije stvoren za takvu vrstu odnosa $\mathrm{s}$ istim spolom poredeći je u krajnjoj konsekvenci $\mathrm{s}$ čovjekoubojstvom. Ova pojava je nespojiva s prirodnim dobrom, očuvanjem vrste, to jest, pretpostavlja destrukciju ljudske egzistencije.

4. Nametanja LGBT ideologije i kulture predstavlja prijetnju uništenja porodice kao osnovne ćelije društva, čime se urušava cijela ljudska civilizacija i čiji fizički opstanak i reprodukcija dolaze u pitanje uz strah i latentnu opasnost da će istospolni brakovi, u slučajevima posvojenja, odgajati homoseksualnu djecu kao i teza da je to neprirodna zajednica jer ne može imati djecu.

5. Homofobija je izraz koji označava negativan stav prema ljudima koji ulaze u seksualno-emocionalne veze s osobama istog spola $u$ vidu homoseksualnih veza i partnerstava.

6. Pod utjecajem diktata međunarodne zajednice, a ne kao plod „sazrijevanja“ društva ili aktivističkog djelovanja zajednice, 
zakonodavstvo kod nas je zabranilo diskriminaciju kroz Zakon o ravnopravnosti spolova i Zakon o zabrani diskriminacije.

7. Provjerenim metodama zamjene teza, politika, lobiji, mediji i elite u svjetskim, globalnim okvirima često izokrenu i izopače stvarnost $\mathrm{i}$ istinu, tako da od nje naprave neistinu, od jahača apokalipse zaštitnika demokratije i borca za ljudska prava i nediskriminaciju, od kukavice heroja, od junaka kukavicu, od dželata žrtvu, a od žrtve dželata, teroristu itd.!

8. Istanbulskoj konvenciji u pravnom smislu mogu se uputiti sljedeće primjedbe:

a) Uvođenje pojma ,roda“ i kvazinaučne „rodne“ teorije,

b) Neusklađenost s Ustavom,

c) Iskorjenjivanje vjere, tradicije i porodičnih/obiteljskih vrijednosti,

d) IDEOLOGIZACIJA - Nametanje rodne ideologije najranjivijim kategorijama društva: djeci u vrtićima, mladima u školama i javnosti u medijima,

e) Princip ,uzmi ili ostavi“.

9. Nema spora $\mathrm{u}$ islamskom pravu da je promocija homoseksualnosti delikt protiv čovječanstva, vjerskih i tradicionalnih vrijednosti, a njegova agresivna javna ideologizacija kroz LGBTIQ kulturu i pokret diskriminira ogromnu većinu čovječanstva.

10. Zbog indolencije ili pod diktatom stranih lobija naši predstavnici uglavnom papagajski ponavljaju kako nemamo ništa protiv tih nastranosti tako da zbog toga sutra očekuje(e)mo zakonsko prisiljavanje vjerskih službenika na "šerijatska homoseksualna vjenčanja”, predškolske, mektepske, školske, nastavne, fakultetske, homoseksualne obrazovne programe; i očekujmo da oni koji se ne slažu s tom ogavnošću, makar bili preko 90\% društva, budu sankcionirani zbog nepoštivanja zakona koji će se tek usvojiti pod diktatom sa strane.

11. Homofobija se koristi kao argument protiv protivnika homoseksualnosti u pokušaju da se heteronormativno društvo natjera na priznavanje ove pojave kao normalne te specijalnim 
zakonskim rješenjima zaštiti od diskriminacije ili da se ta gnusna pojava postavi kao savremeni standard te da se odnosom prema homoseksualnosti "mjeri stepen demokratije u jednoj zemlji." To su sotonistički, uvrnuti, izopačeni standardi koji izazivaju apokalipsu. Demokratija se ne mjeri prema stepenu intenziteta neprijateljstva, nekontrolisane sile ili agresije prema nedužnim civilima, svakodnevnim ubijanjima i uništavanjima čitavih država (krucijalni je razlog što se radi o žrtvama muslimanima), nego po tome hoće li se desiti parade ponosa i sl. To je samo dno antietičnosti i nemorala!

12. Iako postoji konsezus islamskih pravnika i učenjaka o sankcioniranju homoseksualnosti, ipak postoji razilaženje po pitanju pravnog osnova i sankcije za ovaj prijestup, ali koji ne izlazi iz okvira zabranjenosti i smrtne sankcije.

13. Tema homoseksualnosti i sve njene kontroverze, njena supkultura, zaštita i/ili diskriminacija i u narednom vremenskom periodu bit će sve više aktuelna, kako njihovi lobiji budu pojačavali svoju aktivnost i silu jer će se određena pitanja vremenom nastojati pozicionirati i u zakonodavne, parlamentarne vode gdje će oni lobiranjem, obmanama i pritiscima tražiti specijalne propise i zaštitu tako da je davno prošlo vrijeme neutralnosti i indolentnosti, posebno onih koji budu imali određene odgovornosti kao što su parlamentarne strukture države, IZ BiH i njene institucije, jer će se od njih tražiti jasan stav i određenje po ovom pitanju.

14. Coming out kao i parade ponosa u slučaju homoseksualaca i LGBT populacije su neprihvatljive aktivnosti, analogijom se smatraju priznanjem vida bluda i razvrata homoseksualnosti koje prouzrokuje sankciju te zbog toga, u muslimanskom društvu, nikada neće biti dozvoljene aktivnosti jer ne smiju izaći u javnost iz ,četiri zida", inače je društvo u obavezi da ih sankcionira.

\section{IZVORI I LITERATURA}

1. El-Kur'anu-l-kerim, Mushafu-l-Medinetin-Nebevijjeh, Kur'an Časni, medinska verzija Mushafa; Mudžemme'u-l-melik Fehd, (1405. h.)

2. Korkut, Besim. Kur'an s prevodom, S. Arabija, Medina: Štamparija kralja Fehda,

3. (1412. h.) 
4. The Zekr Project El-Kur'anul-kerim,

\section{Knjige i brošure}

5. Abdulkerim Zejdan. (1987) El-Vedžizu fi usuli-l-fikh. Muesseseturrisale.

6. Ahmed b. A'li b. Hadžer El-A'skalani. (1407/1986) Fethul-Bari šerh Sahihul-Buhari.

7. Ahmed b. Ganim, Šihabud-din En-Neferavi. El-Fevakihud-devani. Bejrut: Darul-kutubil-i'lmijje.

8. Ahmed b. Muhammed El-Emin b. Ahmed. (1983/1403) MevahibulDželil min edilletil-Halil. Katar: Idaretu ihjait-turasil-islami.

9. Ahmed b. Muhammed b. Hanbel Eš-Šejbani. (2001/1421) Musned. Muessesetur-risale.

10. Ali b. Ahmed b. Hazm el-Endelusi. (1988) El-Muhalla bi-l-asar. Liban, Bejrut: Daru-1-kutubi-1-'ilmijje.

11. Badri, Malik. (2002) AIDS/SIDA i kriza modernog svijeta u svijetlu islama. Sarajevo: El-Kalem.

12. Banović, Damir i Vasić, Vladana. Seksualna orijentacija i rodni identitet: pravo i praksa u BiH (Terminologija: LGBT rječnik).

Sarajevo: Sarajevski otvoreni centar.

13. Begović, Mehmed. (1961) Porodično pravo. Beograd: Narodna knjiga.

14. Burhanuddin, Ebu-Hasen El-Marginani. El-Hidaje šerh bidajetilmubteda.

15. Ebu Bekr, Ahmed b. Ali El-Džessas. (1992/1412) Ahkamul-Kur'an, Daru Ihjail-kutubila'rebijjeti.

16. Ebu-Zekerijja Muhjuddin b. Šeref en-Nevevi. El-Medžmu'u šerhu-lmuhezzeb (Daru-l-fikr).

17. El-Badži, Ebul-Velid, Sulejman b. Halef. El-Munteka, šerhu-Muvetta Malik. Bejrut: darul-kutubil-i'lmijje.

18. El-Buhuti. Keššaful-kina'. Matbe'atus-sunnetil-muhammedijje.

19. Er-Remli. Nihajetul-Muhtadž. Matbea'tul-behijjetil-masrijje.

20. Es-Serahsi, Šemsud-din. (1989/1409) El-Mebsut. Bejrut: DarulMa'rifeti.

21. Grupa autora. (2012) Čitanka LGBT ljudskih prava (2. dopunjeno izdanje). Sarajevo: Sarajevski otvoreni centar/Fondacija Heinrich Boll.

22. Grupa autora. (2012) Pojmovnik LGBT kulture. Sarajevo: Sarajevski otvoreni centar/Fondacija Heinrich Boll. 
23. Ibn Džerir Et-Taberi. (1984) Džami'u-l-bejan fi te'vili aji-l-Kur'an. Daru-l-Fikr.

24. Ibn-Humam. Fethul-kadir šerhul-hidaje. Matbe'atu Mustafa Muhammed bil-Kahira.

25. Ibn Kajjim El-Dževzijje. Ed-Dau ved-devau. Daru a'lemil-fevaid, tahkik: Muhammed Edžmel.

26. Ibn Kajjim El-Dževzijje. Revdatul-muhibbin ve nuzhetul-muštakin. medžmeu'l-fikhil-islami bi Džidda.

27. Ibn-Kesir. (2000) Tefsir Ibn-Kesir. Sarajevo: Visoki saudijski komitet.

28. Ibn Kudame. (2010) Eš-Šerhul-kebir a'lel-Mukni'i. Darul-kutubilA'rebi litt-tevzi'i ven-nešr.

29. Ibn Kudame, Abdul-Muhsin Et-Turki i dr. Abdul-Fettah El-Hilv.. (1992). El-Mugni. Kairo: Hidžr.

30. Ibnul-A'rebi. (2003/1424) Ahkamul-Kur'an. Darul-kutubil-i'lmijje.

31. Ibn-Rušd El-Kurtubi. Bidajetul-mudžtehid. Mektebetul-istikame bi Misr.

32. Ibn Tejmije. Es-Sijase eš-šer'ijje fi islahir-ra'i vere'ijje. Daru a'lemilfevaid, tahkik: Ali b. Muhammed.

33. Ibrahim b. Muhammed el-Halebi. (1989). Multeka-l-ebhur. Muessesetur-risale.

34. Klaić, Bratoljub. (2004) Rječnik stranih riječi. Zagreb:Nakladni zavod $\mathrm{MH}$.

35. Muhammed b. Ahmed el-Kurtubi. (1985) El-Džamiu’ liahkami-lKur'an. Libanon, Bejrut: Daru ihjait-turasi-1-'Arebi.

36. Muhammed b. Ahmed b. Rušd El-Kurtubi. (1988) Bidajetulmudžtehid ve nihajetul-muktesid. Liban, Bejrut: Darul-kutubil-i'lmijje.

37. Dr. Muhammed Ali El-Barr. (1998) Spolne bolesti, Sarajevo: u izdanju Visokog saudijskog komiteta za pomoć BiH.

38. Muhammed b. Džerir et-Taberi. (1988) Džami'u-l-bejan 'an te'vili ajil-Kur'an, Daru-1-fikr.

39. Muhammed b. Idris eš-Šafi'’i. El-Umm. Libanon, Bejrut: Daru-1ma'rife.

40. Muhammed Nesib er-Rifa'i. (1978) Tejsiru-l-'Alijji-l-kadir lihtisari tefsir Ibn Kesir. Bejrut.

41. Muhammed b. Salih El-U'sejmin. Eš-Šerhul-mumti'u. Daru Ibni Dževzi.

42. Mustafa b. Sa'd, Er-Ruhajbani. (1994/1415) Metalibu ulin-nuhafi šerhi Gajetil-munteha. El-mektebul-islami. 
43. Nacionalni tjednik. Globus. br: 702, 21. 05. 2004.

44. Narodne novine. Službeni list Republike Hrvatske. Obiteljski zakon. Zagreb 11. lipnja 2014.

45. Nasirul-islam Er-Ramfevri. (1990/1411) El-Binajetu šerhul-Hidajeti. Darul-fikri.

46. Nerimana Traljić \& Suzana Bubić. (2007) Bračno pravo. Sarajevo: Pravni fakultet Univerziteta u Sarajevu.

47. Porobija, Željko. (2011) Povijest razvoja teologije od apostolskih otaca do konca srednjega vijeka. Maruševac: Adventističko teološko visoko učilište.

48. PORODIČNI ZAKON OBJAVLJEN U SLUŽBENOM GLASNIKU $R S$ BROJ 18/2005 OD 24. 2. 2005. (primjena 1. jula 2006.)

49. PORODIČNI ZAKON ("S1. glasnik RS", br. 54/2002, 41/2008 i 63/2014),

50. Zekijjud-din El-Munziri. (1968) Et-Tergibu vet-terhibu minel-hadisiššerif. Muessesetut-tarih vet-turasil-arebi.

\section{Internet:}

51. Papa Frane: Postoji 'gay lobby' u Rimskoj kuriji - sam ne mogu provesti reformu,

http://www.slobodnadalmacija.hr/Svijet/tabid/67/articleType/ArticleVi ew/articleId/212730/Default.aspx, posjećeno, 29. septembra 2019.

52. https://direktno.hr/zivot/obitelj/vigilare-pisao-blazenki-divjak-hoceteli-dozvoliti-ulazak-vrtice-i-skole-slikovnicama-s-istospolnim-109079/, pristupljeno 04. janura 2018.

53. https://ar-

ar.facebook.com/Astawso.Belnesaa2.../51286493214464...pristupljeno 10 , pristupljeno $\mathrm{u}$

54. novembru, 2017.

55. Charles W. Socarides, M.D., How America Went Gay (http://www.theroadtoemmaus.org/(RdLb/22SxSo/PnSx/HSx/SocrdsH owAmerGay.htm). Posjećeno, 25. septembra, 2019.

56. www.novihorizonti.ba/poligamija-visezenstvo/, pristupljeno, 18. novembra 2017.

57. https://id.scribd.com/document/.../Dr-Zakir-Naik-Poligamija-u-Isla..., posjećeno, 18. novembra, 2017. 
58. https://direktno.hr/zivot/obitelj/vigilare-pisao-blazenki-divjak-hoceteli-dozvoliti-ulazak-vrtice-i-skole-slikovnicama-s-istospolnim-109079/, pristupljeno 4. janura, 2018.

59. Vidi: https://www.logicno.com > Politika, pristupljeno, 2. januara, 2018.

60. Autor: Z. K.Petak, 15. rujan 2017. u 15:53, Ono na što su mnogi upozoravali, sad se obistinjuje

61. (Referendum o ustavnoj definiciji braka u Hrvatskoj Wikipedija hr.wikipedia.org/wiki/Referendum_o_ustavnoj), pristupljeno, 1. augusta, 2016.

62. Referendum o braku: Ovo su države u kojima je istospolni brak ...

63. dnevnik.hr/.../referendum-o-braku-ovo-su-drzave-u-kojima-je-ist., pristupljeno, 25. jula 2016.

64. Odgojile su me lezbijke i protivim se gay brakovima - Zdravstveni odgojzdravstveniodgoj.com/.../odgojile-su-me-lezbijke-i-protivim-seg..., pristupljeno, 25. jula 2016.

65. forum.krstarica.com/showthread.php/789889-Senzac..., posjećeno, 29. jula, 2017.

66. www.fbihvlada.gov.ba/bosanski/zakoni/2005/zakoni/25bos.pdf

67. https://advokat-prnjavorac.com/zakoni/porodicni_zakon_RS.pdf

68. PDF]Porodicni Zakon Republike Srpske, Bosna i

Hercegovinahttps://advokat-

prnjavorac.com/zakoni/porodicni_zakon_RS.pdf

69. Porodični zakon Republike Srpske - Paragraf Lex BA www.paragraf.ba/propisi/republika-srpska/porodicni-zakon.html

70. Porodični zakon - Paragraf www.paragraf.rs/propisi/porodicni_zakon.html 


\title{
HOMOSEXUALITY IN THE MIDDLE OF FAITH, TRADITION, BEAUTIFUL, ACCEPTABLE CUSTOMS AND A HEALTHY HUMAN NATURE
}

\author{
PhD Muharem Štulanović, Islamic Faculty of Pedagogy \\ University of Bihać \\ E-mail:ebuseba@hotmail.com
}

\section{Abstract}

Following the decriminalization of homosexuality and removal from the list of disorders, members of the LGBTIQ community, their activists, continued to fight for their unique, special rights, publicity and legal equalization with the heterosexual community. These include the protection of the human rights of homosexuals, legal recognition of same-sex couples, recognition of sexual orientation and gender identity as grounds on which discrimination is not permitted, including all other rights used by the community.

In our country, under the influence of the international community, and not as a result of the inner workings of any activist entities or the "maturation" of a democratic society, discrimination through the Gender Equality Act and the Anti-Discrimination Act is prohibited.

Because this is a complete alternative culture to the opposite of heavenly, revealed, faith, the absolute majority of the world's population is opposed to homosexual ideology, regardless of the legal solutions, declarations, and legal status that the LGBT population has endured. People of common sense, tradition, beautiful, acceptable customs are horrified by the grave and even apocalyptic consequences that this population could cause (an attempt to overthrow the family and basic universal moral values, various new diseases unknown in past times that accompany this population, depopulation and white plague, etc.). It is certain that behind the social, political and legal affirmation of this population are some of the world's elites and certain very influential lobbies and centers of power (Masonic, Jewish, Porn, Pharmaceutical, Satanic, Gender and others).

Coming out and pride parades, gay people achieve their social engagement, specific activities, ideology, and public outreach, and build their own subculture. counter-culture or alternative that resists dominant heterosexual culture. Recently, significant changes have been made in our region in adopting 
legislation imposed by external factors and social and legal pressures that should protect this population from homophobic behavior. Thus, in recent years, the attitude towards homosexuals has been eased in our country, as it has previously happened globally, in the West. Their subculture is also being imposed on our territories in different fields and spheres of social life through art (literature, culture, music, theater, film, painting, photography, festivals, comics...), the activities of an increasing number of LGBT organizations, their activism. with extensive use of the media, especially the internet, but also the rights and politics, through a strong foreign lobby and the influence of world power centers.

Their campaign for legal rights and equality in society, under the guise of tolerance and protection of human rights, the fight against discrimination, stereotypes and homophobia, with the use of ultimatums by certain external centers of power led to the adoption of legal acts, declarations, resolutions to protect the rights of LGBT people globally as well as nationally and regionally.

Since this is a specific target group, special rights, special culture and movement, in the paper we have particularly criticized the Istanbul Convention and two models of their public struggle for recognition and nondiscrimination (Coming out and Pride parades) because these are current issues that are trying to be implemented in our area with help coming from outside our country.

KEYWORDS: homosexuality, LGBTIQ population, sexual orientation, gender, gender ideology, gender identity, coming out, pride parades. 


\author{
الأستاذ الدكتور محرم شتولانوفيتش \\ جامعة بيهاتش \\ كلية التربية الإسلامية \\ E-mail:ebuseba@hotmail.com
}

\title{
اللوطية في ميزان الدين والتقاليد والعادات الجميلة المقبولة والفطرة الإنسانية السليمة
}

\section{الملخص}

بعد إلغاء تجريم اللوطية والمثلية الجنسية وإزالتها من قائة الاضطرابات، واصل أفراد

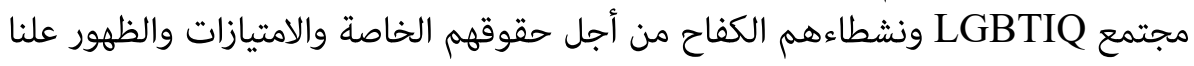

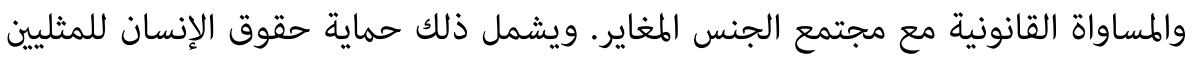

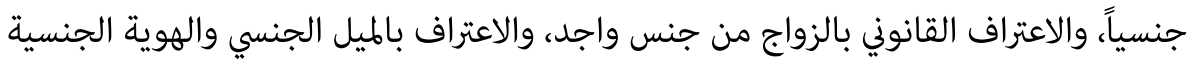

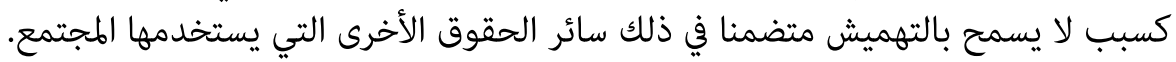

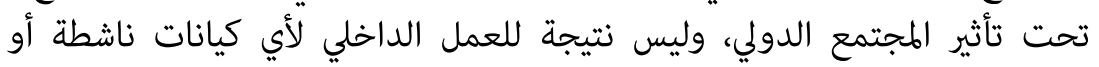

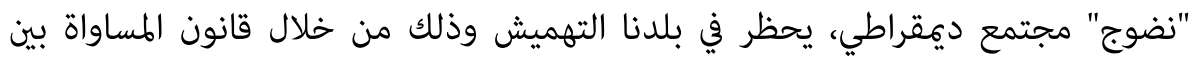
الجنسين وقانون مكافحة التهميش.

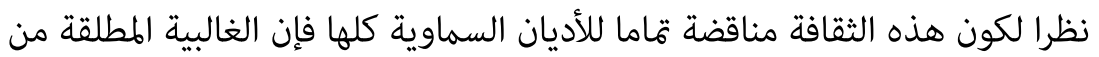

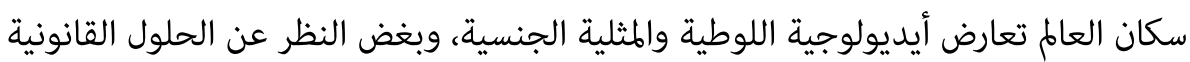

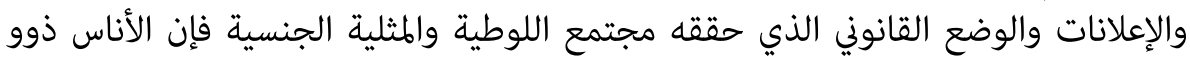

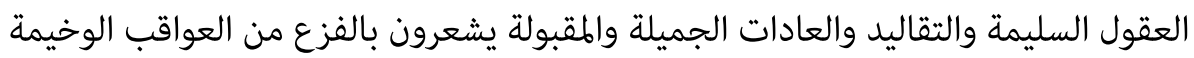

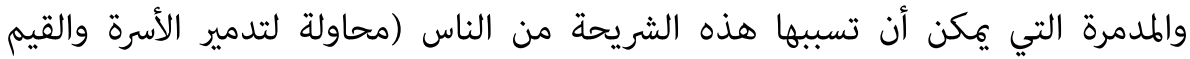

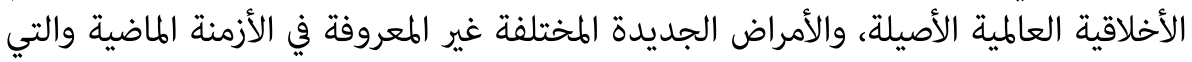

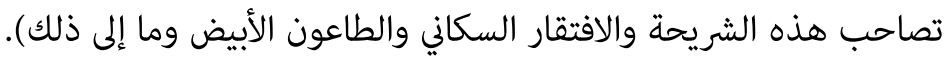

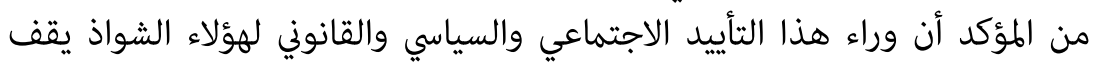

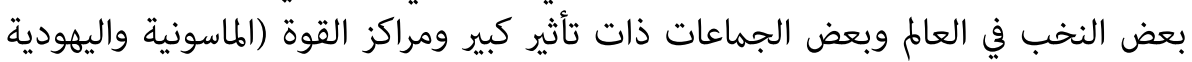
والإباحية والصيدلانية والشيطانية وغيرها).

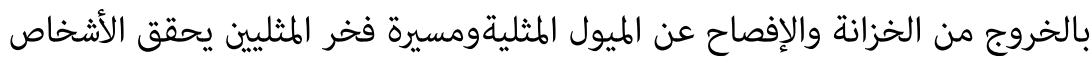

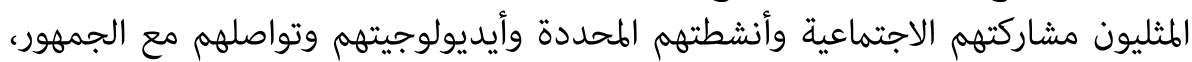

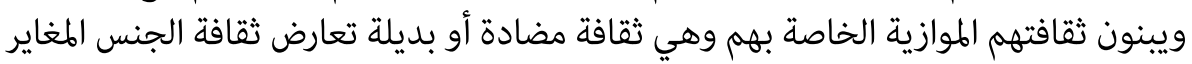

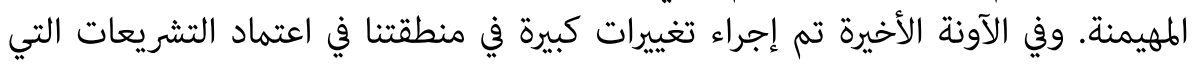

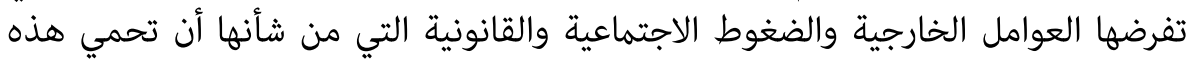

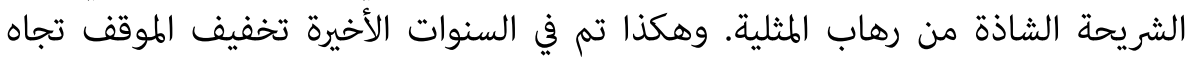


المثليين جنسياً في بلدنا، كما حدث ذلك على مستوى العام في الغرب. كما تُفرض ثقافتهم

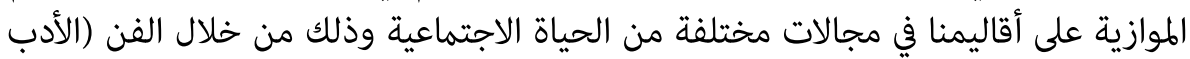

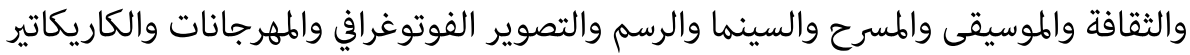

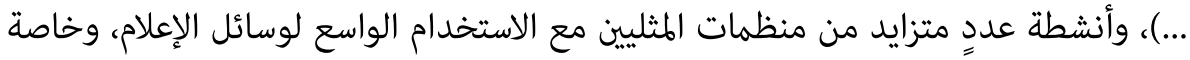

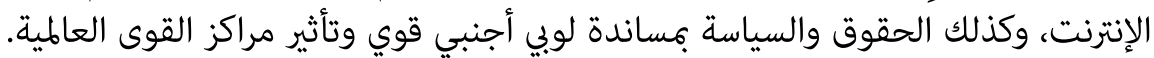

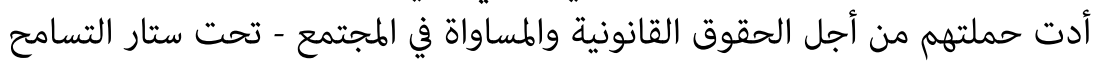

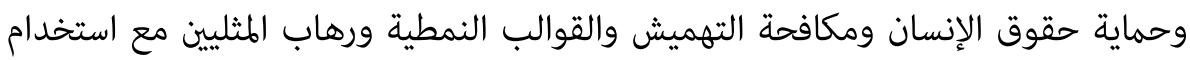

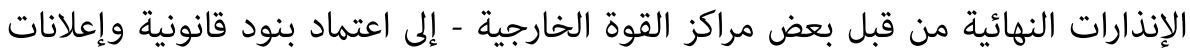
وقرارات بشأن حماية حقوق المثليين عالميا وكذلك وطنيا ونيا وإقليميا.

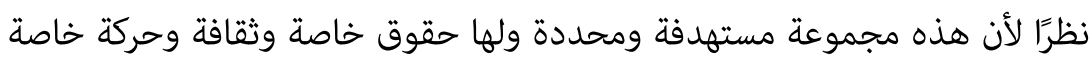

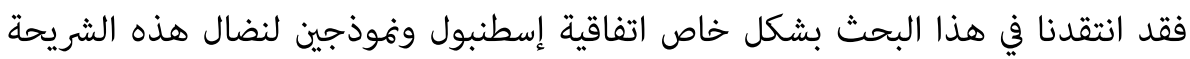

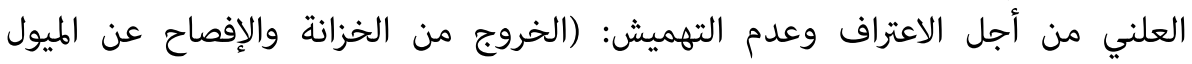

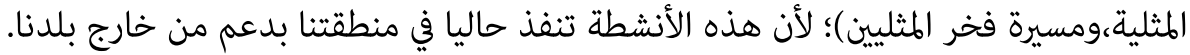

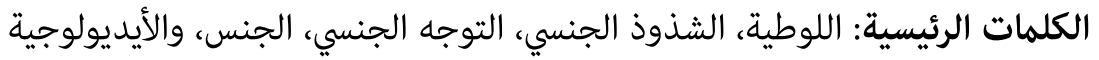

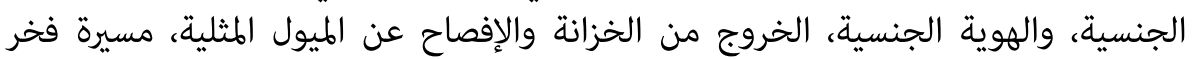
المثليين. 